\title{
The Case for REITs in the Mixed-Asset Portfolio in the Short and Long Run
}

\author{
Stephen Lee, The University of Reading ${ }^{\dagger}$ \\ \& \\ Simon Stevenson, University College Dublin and Cass Business School, City University $\ddagger$ \\ ${ }^{\dagger}$ Centre for Real Estate Research, Department of Real Estate \& Planning, Business School, \\ The University of Reading, Reading, RG6 6AW, England \\ Phone: +44 118931 6338, Fax: +44 118931 8172, E-mail: S.L.Lee@reading.ac.uk \\ ‡ Centre for Real Estate Research, Smurfit School of Business, University College Dublin, \\ Blackrock, County Dublin, Ireland. \\ Phone: +353 1716 8825, Fax: +353 1283 5482, E-mail: simon.stevenson@ucd.ie \\ Real Estate Finance \& Investment Group, Faculty of Finance, Cass Business School, City University, 106 Bunhill \\ Row, London, EC1Y 8TZ, England
}

\begin{abstract}
The poor performance of the Stock Market in the US up to the middle of 2003 has meant that REITs are increasingly been seen as an attractive addition to the mixed-asset portfolio. However, there is little evidence to indicate the consistency of the role REITs should play a role in the mixed-asset portfolio over different investment horizons. The results highlight that REITs do play a significant role over both different time horizons and holding periods. The findings show that REITs attractiveness as a diversification asset increase as the holding period increases. In addition, their diversification qualities span the entire efficient frontier, providing return enhancement properties at the lower end, switching to risk reduction qualities at the top end of the frontier.
\end{abstract}

Keywords: Mixed-asset portfolios, REITs, Marginal impact 


\section{The Case for REITs in the Mixed-Asset Portfolio in the Short and Long Run}

\section{1: Introduction}

The REIT market in the US offers investors a way to invest in real estate without the problems of illiquidity, intense management and large lot size/high unit cost (Ciochetti et al., 2002). Recent years have seen increased investor interest in the REIT sector for a number of reasons. The combination of factors such the limitations on REITs in relation to dividend payments and the strong relative performance of the sector in the aftermath of the collapse of the technology bubble have resulted in increased fund flows into the sector (Ling \& Naranjo, 2003). Furthermore, the low correlation of REITS with the US stock market in the late 1990s led to claims that REITs offered excellent diversification benefits to a mixed-asset portfolio as well as improved return performance (NAREIT, 2002). In addition, the inclusion of REITs into major general equity indices such as the S\&P500 has also increased awareness and investment, particularly from index based fund managers. Hence, increasing numbers of investors are considering adding REITs to their existing mixed-asset portfolio of stocks and bonds. However, there is as yet no consensus as to whether REITs should be included in a mixed-asset framework ${ }^{1}$. In addition, investors have differing holding periods and they might reasonably question whether the performance of REITs will remain competitive with other assets over both short- and longrun investment horizons. In other words, there is little or no evidence to indicate whether REITs would play a consistent role over varying time periods and at what percentage?

To address the question, the allocation of REITs in optimal mixed-asset portfolios is evaluated over different holding periods varying from 5- to 20-years. The incremental impact upon both risk and return is examined from the inclusion of REITs into the optimal portfolios. This is achieved by comparing the risks of portfolios on the efficient frontier with and without REITs for the same level of return and the return of portfolios on the efficient frontier with and without REITs at the same level of risk. The general conclusions of which are that REITs do fairly consistently provide both return enhancement and risk reduction benefits. While, this does vary to some extent over time, it is broadly consistent over the various time periods analysed. The results also illustrate that REITs provide the greatest benefits in the low risk and return optimal portfolios, with the results less obvious at the high risk/return end of the efficient frontier. Finally, the benefit from holding REITs appears to shift as an investor moves across the efficient frontier. At the lower end of the frontier it would appear that greater benefits are due to the return enhancement qualities of REITs. However, at the higher end of the frontier, the sectors risk reduction qualities come to the fore.

\footnotetext{
${ }^{1}$ See Corgel et al. (1995) and Zietz et al. (2003) for comprehensive reviews.
} 
The remainder of the paper is organised as follows. The next section discusses some of the existing empirical evidence in relation to REITs. Section 3 describes the research design and data used in this study. Section 4 reports the empirical findings, while Section 5 contains concluding remarks.

\section{2: Previous Studies}

Do REITs offer diversification benefits to a Mixed-Asset Portfolio?

Using monthly data Kuhle (1978) examined the effect of including equity REITs (EREITS) or mortgage REITS (MREITs) into a portfolio of common stocks on Sharpe Ratios for the period 1980 to 1985 . The author concludes that REITs do not add significant performance benefits to a portfolio of only common stocks. In contrast, Mueller et al (1994) shows that EREITs were a valuable addition in a mixed-asset framework for the 1976-1980 and 1990-1993 time periods but not for the 1980-1990 sub-period. Mull \& Soenen (1997) also find that the value of REITs as an asset class is time dependent. While, Ibbotson Associates, on behalf of NAREIT (NAREIT, 2002), showed that adding REITs to a mixed-asset portfolio, would have offered considerable benefits in terms of portfolio performance over the last 30 years.

\section{Are REITs Integrated with Direct Real Estate?}

The above studies generally do not consider the inclusion of REITs within a mixed-asset framework when the investor already owns direct real estate. This is important since if REITs are a direct substitute for real estate then they would have no place in portfolios which already had a holding in private real estate. Several authors have, therefore, investigated whether REITs are integrated with the direct real estate market, since if the two markets are co-integrated, then there exist common factors that affect both returns and so the series' will eventually adjust to equilibrium. Thus, the perceived diversification benefits of REITs within optimal portfolios will be eroded away when the returns of direct real estate are also considered. In other words, REITs would be operationally redundant in the long run for an investor who already owns direct property.

Gyourko \& Kiem (1992) find that lagged REIT returns predict the returns of the direct market, after controlling for appraisal persistence. Myer \& Webb (1993), Campeau (1994) and Barkham \& Geltner (1995) all find that the public market "Granger" causes changes in the private market but that the reverse does not hold. Campeau (1994) investigated the long-run relationship that exists between the private and public markets and finds that the two are integrated. Glascock et al (2000) also found that REITs were co-integrated with the private real estate market. Clayton and MacKinnon (2001) find that the sensitivity of REIT returns to private real estate showed a significant increase in the 1990s, indicating that REITs are more integrated with private real estate than financial assets. These findings indicate that that the public real estate market provides information about real estate performance that is subsequently impounded into the direct market and that the public market leads the private market. In 
addition, the studies show that REITs behave differently from the direct real estate market in the shortterm but that over the long-run REIT returns equate to those of the private real estate market. In other words, when considering REIT returns and the returns from the direct market in the short-run both may have a place in optimal portfolios, but in the long-run one is a substitute for the other and so only one may have a place in optimal portfolios.

Feldman (2003) and Mueller \& Mueller (2003), however, both show that even if the optimal portfolios already contained real estate from the private market, a holding in REITs would still lead to improvements in portfolio performance. Using annual data over the period from 1987-2001, Feldman (2003) finds that both public and private real estate have a place in a mixed-asset framework. The paper uses two alternative measures of the direct market in addition to the standard NCREIF Index. When the original index is used the maximum allocations obtained are $15 \%$ in REITs and $30 \%$ in private real estate. These figures alter to $12 \%$ and $18 \%$ and $13 \%$ and $8 \%$ when the variable-liquidity and the constant-liquidity return indices for the direct market are used respectively. Mueller \& Mueller (2003) extend the analysis of Feldman (2003) to examine the impact of private and public real estate on the mixed-asset portfolio for various holding periods for the last 5 to 25 years up to 2002. The authors find that for the full sample period the inclusion of private real estate as measured by the NCREIF index, ether appraisal based or de-smoothed, led to improvements in the performance of the efficient frontier at the lower risk levels, while REITs provided improvements to the entire frontier. A result supported by the findings for the 5- to 15-year sub-periods. Stevenson (2001b) examines the improvement in portfolio performance from the inclusion of both REITs and international real estate securities into direct market portfolios. The findings indicate that while REITs obtain substantial allocations in the optimal portfolios, only in the case of assuming a diversified direct portfolio and the inclusion of international real estate vehicles, is the improvement in performance statistically significant.

\section{Are REITS Co-integrated with the Stock Market Indexes?}

Using a co-integration approach Li \& Wang (1995) note that REITs are integrated with the general stock market over the period from 1971 to 1991. Oppenheimer \& Grissom (1998) using spectral analysis make a similar conclusion, finding that stock market indices have a dominant influence on REIT returns over the period from 1989 to 1995 . This is a view supported by Ling \& Naranjo (1999), who found that REIT returns were integrated with the non-real estate stock market between 1978 and 1994 and that this integration increased during the 1990s. A view shared by Glascock et al (2000) who tested for integration among EREITs, MREITs, bonds and common stocks from 1972 to 1997 . The authors showed that from 1972 to 1991, REITs were segmented from the common stock market, while they were integrated from 1992 to 1996 . Consequently, REITs would offer little benefit after 1992. In addition, the authors find that prior to 1992 the returns of EREITs and MREITs both behaved like bonds, but that EREITs acted more like stocks after 1992, while MREITs continued to act like bonds. Clayton \& 
MacKinnon (2001) find that the sensitivity of REIT returns to the Stock Market has declined significantly in the 1990s. A finding they attribute to the growth and maturity of the REIT market.

\section{Do REITs have Style?}

If the returns of REITs returns could be mimicked by capital market indices there would be little point in having REITs as part of the mixed-asset portfolio as their returns can be replicated by other assets classes. In contrast, if REITs cannot be duplicated by the returns on other assets they are unique and so will contribute to the performance of the optimal portfolios. Using the style analysis approach of Sharpe $(1988,1992)$ a number of studies have shown that REITs are a "unique" asset class and so should lead to improved risk-adjusted performance when added to the optimal set. Using the returns from five asset classes to identify the "style" of REIT returns, Liang \& McIntosh (1998) find that REITs were a "unique" asset class from 1993-1997 and should have been included in mixed-asset portfolios. However, the authors do not consider the returns of the private real estate market in developing the style of REITs. This is important as the indexes used in return based style analysis need to be exhaustive otherwise the "true" style will be missed. In order, to rectify this Chiang and Lee (2002) included value and growth indices and the returns from the private real estate market to identify the style of REIT returns over the period from using a 36-month rolling estimation. The authors found that the style of ALL REITs can be classified as small value stocks while EREITs behave more like value stocks and T-Bills. In contrast, MREITs primarily load on corporate bonds. Stevenson (2001c) finds similar results in the UK, with small-cap and value indices providing $50 \%$ of the style of property companies. This implies that REITs can be classified as a small value stocks. Nonetheless, Chiang \& Lee (2002) find that since the styles of EREITs and MREITs display instability over time it would make it difficult for investors to create ex ante mimicking portfolios out of the ex post style of REITs. Similar findings are reported by Sanders (1998) who showed that REITs, over the period 1978 to 1996, could be replicated by four indices, which explained $70 \%$ of the variation in REIT returns. However, Sanders (1998) also notes that the weights of these indices in explaining REIT returns changed markedly over the period used. The $30 \%$ unexplained also indicates that mimicking portfolios cannot be adequately achieved by a mixture of other assets. Clayton \& MacKinnon (2001) also find that the correlation of REIT returns with financial assets is time-varying, suggesting that REIT cannot be satisfactorily duplicated in an ex ante framework. This suggests that REITs need to be treated as a separate asset class and so should play a role in mixed-asset portfolios.

\section{Which Stock Market Indices are correlated with REITs?}

Clayton \& MacKinnon (2000) find that REIT return volatility was largely explained by large-cap stocks, followed by small-cap stocks and then bonds, indicating that REITs are a hybrid of small cap stocks and real estate. In contrast, Mueller et al (1994) find that REITs had similar returns as small cap stocks. A finding supported by Liang \& McIntosh (1998) who show that REIT returns behave like a portfolio 
containing 40\% small-cap stocks and 60\% bonds plus T-Bills. Sanders (1998) finds that REIT returns are most closely associated with the Wilshire Small Value index and high-yield corporate bond index. However, the author notes that this relationship became more complex after 1993. A similar result to that of Chiang \& Lee (2002) who found that EREITs have become increasing more closely associated with small-cap value indices. While, Ziering et al (1999) shows that REIT returns were becoming more disconnected from large-cap stocks and moving closer to the performance of value and growth indices. Clayton \& MacKinnon (2001) note that the correlation of REIT returns with stocks and bonds underwent a structural change in the 1990s, with the sensitivity of REIT returns to large-cap stocks declining over time, while that with small-cap stocks increased. More specifically in relation to volatility, Stevenson (2002) examines volatility spillovers in REITs. The results indicate that volatility in REITs is influenced to a far greater extent by volatility in small cap stocks and value stocks. In contrast, the S\&P500 has a mixed and inconsistent relationship with the REIT sector. Interestingly, there is no evidence of spillovers in volatility from either the Treasury bill or fixed income sectors to MREITs.

In summary, a review of previous work reveals the following:

- $\quad$ REITs behave like direct real estate in the long run but more like financial assets in the shortrun.

- $\quad$ REITs were integrated with the stock market up to the 1990s, since which time they have begun to behave more like direct real estate market.

- $\quad$ REITs behaved more like large-cap stocks in the 1970s and 80s but since the early 1990s REITs have performed more like small-cap value stocks.

- $\quad$ REITs are a "unique" asset class, whose returns cannot be replicated with other assets.

- $\quad$ REITs may offer improvements in a mixed-asset context, but this is likely to depend on the time period considered and the length of the holding period.

Thus, using data from 1980 to 2002 this paper attempts to answer the question of whether REITs have a consistent place in optimal portfolios by considering, holding periods from five to twenty years and a pre existing set of optimal portfolios consisting of a wide range of asset classes.

\section{3: Research Design \& Data}

To investigate the issue of whether REITs have a position in efficient portfolios over varying time horizons, efficient frontiers were estimated for a range of 4 alternative rolling time periods, with the overall data set used beginning in 1980 and ending in 2002. The time horizons used were 5-years, 10years, 15-years and 20-years. Therefore, the first five-year portfolios were estimated using data from 1980 through to the end of 1984, with the last using data for 1998 through 2002. A total of 19 5-year horizons were used, 14 10-year periods, 9 15-year periods and finally 4 20-year periods. For each 
rolling period, three efficient frontiers were calculated. In the first, REITs were not permitted to enter the optimal solution while in the remaining two they were. The objectives of such an approach are threefold. First, to determine whether REITs have a consistent place in the efficient portfolios and what percentage of the total portfolio was allocated to REITs when they did so. Secondly, to see whether REITs increased portfolio returns over portfolios that contained no allocation to REITs and the degree of return enhancement at each level of risk. Finally to see whether REITs reduced portfolio risk over portfolios that contained no holding in REITs, and the degree of risk reduction at each level of return.

The efficient frontiers were each made up of twenty portfolios, where each portfolio represents a specific asset allocation, expected return, and standard deviation. The lowest returns and standard deviations were associated with portfolio 1, the minimum variance portfolio (MVP); progressing through to portfolio twenty, which had the highest, risk and return. The optimal portfolios excluding REITs were initially estimated. For the return enhancement tests, the portfolios were then re-estimated fixing the variance of each of the portfolios and examining, firstly whether REITs entered the optimal portfolios and secondly examining the level of return enhancement observed. Likewise, for the risk reduction analysis, the portfolio return from the initial portfolios was fixed, with comparisons made with the risk when REITs were allowed to enter. Returns, standard deviations, and REIT allocations for each portfolio were then averaged within each holding period. That is for the 5-year holding periods, a total of 19 observations were available for each portfolio. Fewer observations were available for successively longer periods, with 14 observations for the 10-year holding periods; 9 observations for the 15-year investment horizon and 4 for the 20-year investment horizon.

The analysis included a variety of US and international capital market indices. The overall NAREIT index was used to proxy the REIT sector. This index was used in preference to the Equity REIT index. With regard to this decision it should be noted that the focus of the paper is not REITs as a proxy for the direct real estate market. If this was the aim, then it would have been reasonable to use just the equity sector given the different characteristics of both the mortgage and hybrid sub-sectors. Rather the focus of the paper is an examination of the role of REITs within a capital market mixed-asset portfolio; therefore it is only reasonable to include all available REITs. Secondly, it should also be noted that as of the end of 2003 out of a total of 171 REITs, 144 were EREITs, with the equity sector accounting for $91 \%$ of the total REIT market capitalisation. Therefore, given the dominance of Equity REITs, the two indices behave in a very similar fashion. For the general equity market a number of indices were used. The S\&P 500 Composite proxied the large cap sector. The Wilshire indices were used to represent the mid, small and micro cap sectors. The mid cap and small stock groupings were also separated into value and growth stocks. The Datastream indices were used for the US government bond sector, with a range of maturities used. These included 1-3 years, 3-5, 5-7, 7-10 and over 10 years. Treasury Bill yields proxied cash holdings. Finally, the $\mathrm{MSCl}$ indices were used to represent Asian and European equity 
markets. In the case of both of these markets the returns used were in US Dollars, therefore no foreign exchange exposure is present in the analysis. Therefore, the analysis contains a total of six domestic equity indices, two international equity indices, five bond indices and cash.

While the empirical analysis is conducted on a rolling basis, for illustrative purposes the summary statistics of the different asset classes over the entire sample period are reported in Exhibit 1. The results highlight a number of issues that will be raised in the discussion of the empirical analysis. The summary statistics illustrate that to some extent REITs sit between the equity and fixed income sectors. In comparison to equities they produce lower average monthly returns, however, this is compensated for by lower risk figures. This is true for any of the domestic or foreign equity indices. Likewise, in comparison to the bond sector, they produce substantially higher average returns, but this is not at the expense of the increase in risk figures witnessed in the stock market. Indeed, if one compares REITs with long-term government bonds it can be seen that REITs have only marginally higher standard deviations (3.57\% versus $3.34 \%)$ but their average returns are substantially higher $(0.99 \%$ versus $0.14 \%)$. In relation to the correlation coefficients, despite the evidence that REITs have become more equity like in the short-run since in the early nineties, the correlation coefficients reported with regard to REITs are the lowest reported with respect to any of the equity sectors. In addition, not surprisingly, the equity indices with which REITs have the highest reported correlation coefficients are the Wilshire mid and small cap value indices. In addition, despite the low reported correlations with equities, the coefficients reported with respect to the fixed income sector are not consistently or substantially higher than equities. While they are the highest reported in comparison to stocks, they still illustrate the diversification potential of the asset.

$\{$ Insert Exhibit 1\}

Constraints were imposed on the allocations of both REITs and the other capital market asset. This was done in order to address the issue of estimation error. Michaud $(1989,1998)$ argues that optimisers are essentially "estimation-error maximisers" in that risk and return inputs are invariably subject to estimation error, even using historic data. As a result optimisers significantly overweight those assets with large estimated returns, negative or low positive correlation and small variances. This means that the expected return of the optimal portfolio is overstated, whilst its risk is understated. Furthermore, this problem is exacerbated as the number of assets increases with the errors accumulating rather than cancelling. In addition, as the mean-variance model used above does not allow for short sales this significantly increase the adverse effect of estimation risk on the portfolio selection process (Jorion, 1992). Accordingly the successful examination of REITs in an efficient portfolio setting requires a 
procedure that lessens the impact of estimation risk on portfolio construction2. This was achieved by placing restrictions (upper and lower bounds) on the amount which any one asset, or group of assets, can have in the optimum portfolios as it 'constrains' the impact of instability in the input parameters?

The constraints placed on the portfolio were the following. The S\&P 500 was constrained to a minimum allocation of $30 \%$, with a minimum of $40 \%$ in equities in total. The combined bond sector was constrained to a minimum allocation of $20 \%$ and a maximum of $50 \%$, while Treasury Bills were limited to an upper bound of $5 \%$. The combined international equity allocation was constrained to a maximum allocation of $20 \%$ to reflect home bias. Finally, REITs themselves were constrained with an upper bound of $20 \%$. While this may be a relatively high maximum allocation, the $20 \%$ bound in REITs is not intended to reflect the portfolio policy of any known institutional investor. Rather, the intent of this study is to explore how REITs affect overall portfolio risk and return, consequently, the constraint on real estate was therefore kept rather loose.

\section{4: Empirical Results}

The empirical results examine the return enhancement and risk reduction benefits of incorporating REITs into a mixed-asset framework. As stated in the previous section, initially over the four different horizons, twenty efficient portfolios are estimated with the constraints specified, excluding REITs. REITs are then allowed to enter the portfolios, firstly holding the initially estimated portfolio variance's constant, and then the portfolio return. The results reported examine both the estimated allocation of REITs and the level by which firstly the portfolio return is enhanced and secondly how much the portfolio variance is reduced.

Exhibits 2 and 3 present the percentage of the time when REITs achieved a positive allocation in the mixed- asset portfolio and the percentage of the time REITs reached their upper bound, for the four different investment horizons, for the two tests (return enhancement, risk reduction) and for 20 portfolios on the efficient frontier ${ }^{4}$. REITs were a component of optimised portfolios in almost ever period and in most portfolios on the efficient frontier. For instance, at the lower end of the risk/return frontier REITs tended to enter the mixed-asset portfolio almost 100 percent of the time, especially with the longer investment horizons. In contrast, the number of times a positive allocation to REITs occurs declines as we move up the efficient frontier, with REITs never entering the maximum return portfolio (20) at any investment horizon.

2 The issue of estimation error in a real estate context has recently been examined in depth by Stevenson (2001a) and Hoesli et al. (2004). Both of these papers adopt a Bayes-Stein estimator approach to the issue.

3 See Frost \& Savarino (1988), Chopra (1993), Chopra \& Ziemba (1993) and Stevenson (2000).

${ }^{4}$ Detailed results on the allocations across all four investment horizons are presented in Panels $A$ of Exhibits $1 \mathrm{~A}$ to $4 \mathrm{~A}$ the appendix 
The allocations to REITs are, however, dependent on the time period considered as shown by Panel A of Exhibits $1 \mathrm{~A}$ to $4 \mathrm{~A}$ in the appendix, which present the individual results. For instance, for the five-year investment horizon Panel A of Exhibit $1 A$ shows that while REITs obtain substantial allocations across the frontier in the earlier time periods, for much of the late eighties/early nineties the allocations are both far smaller and limited in terms of the number of portfolios. This trend however reverts towards the end of the sample. These results are consistent with the findings above that the returns of REITs behaved more like bonds in the 1980s and acted more like stocks in the 1990s, but that this sensitivity of REIT returns to the stocks declined significantly towards the end of the decade as REITs became more closely aligned with small cap value stocks. In other words, REITs would be a strong replacement for fixed income securities in the 1980s but would lose out to stocks in the early 1990s but regain their position at the start of the new millennium.

$\{$ Insert Exhibits $2 \& 3\}$

Exhibit 2 also shows that REITs tended to reach their maximum allocation of $20 \%$ in the lower to middle risk/return portfolios depending on the investment horizon. For instance, with the five year horizon, REITs reaches their upper bound about a third of the time for the middle level portfolios (11-13) whereas this percentage quickly falls away for the upper and lower portfolios. In contrast, when the twenty-year horizon is considered, REITs tend to reach their maximum allocation three quarters of the time at the lower levels of the efficient frontier (portfolios 4-11), and 50\% of the time for the portfolios 1-3 and 12-13. Indeed, examination of the mean return and risk parameters for the individual time periods indicates that in most cases REITs showed both lower risk and return than the competing asset classes. This would therefore limit its ability to act as a strong portfolio asset at the high end of the frontier. This suggests that REITs are much more of a substitute for low risk low return investments such a fixed interest securities than stocks. As Exhibit 3 shows these results are almost identical when REITs are tested for risk reduction.

Exhibits 4 and 5 provide the summary results in relation to return enhancement and risk reduction for the four time horizons ${ }^{5}$. The figures contained in Exhibit 4 firstly relate to the average allocation for each of the twenty portfolios and secondly the average level of return enhancement. A number of trends are clearly observable from these findings. Firstly, in line with the results above, REIT allocations are concentrated in the low and medium risk/return portfolios. However, while allocations in the mid-range are not substantially different from those in the low risk/return portfolios, the average level of return

\footnotetext{
${ }^{5}$ Detailed results on the return enhancement of REITs on the mixed-asset portfolios across the four investment horizons are presented in Panel $B$ of Exhibits $1 \mathrm{~A}$ to $4 \mathrm{~A}$ the appendix. The corresponding results on risk reduction are presented in Panel $B$ of Exhibits 5A to 8A in the appendix.
} 
enhancement is greater at the lower end of the frontier. For instance, for the five-year investment horizons the average return enhancement is between 7.6 and 3.6 basis points for portfolios 1-5. In contrast, for portfolios 10-15 the gain in return from an allocation to REITs is only about 2 basis points. This greater benefit at the lower end of the efficient frontier could well be due to the fact that in these portfolios REITs are obtaining allocations at the expense of the fixed income sector, and are therefore providing greater increases in portfolio return. While REITs are still obtaining high allocations further up the efficient frontier, in the middle portfolios they are largely competing for allocations against the equity sectors, therefore the perceived advantages in terms of improved return are not so great. The final main finding relates to the differences across the four different horizons. While the average aggregated level of return enhancement does not differ substantially across the four horizons, the average allocations do. Apart from the four highest risk/return portfolios the average REIT allocation increases as the time horizons is increased. For example, while the average allocation in the minimum variance portfolio is $9.46 \%$ when five year rolling horizons are used, this increases to $11.32 \%$ to $13.70 \%$ and finally to $16.25 \%$ for twenty year horizons. As noted, only in the four highest risk/return portfolios is this trend not apparent. Indeed, in the highest risk/return portfolio REITs fail to obtain an allocation in every single case. These findings would indicate that REITs are more attractive and provide greater benefits to investors with longer time horizons.

$\{$ Insert Exhibits 4 \& 5\}

Exhibit 5 provides the corresponding results when risk reduction is examined. As with the return enhancement results, REITs tend to obtain higher allocations in the low and medium risk/return portfolios, with a reduced presence at the high risk/return end of the efficient frontier. As already stated, given the relatively low risk/return nature of REITs in comparison to general stocks, this is not particularly surprising. The sensitivity of optimal portfolio weights, as observed in the return enhancement tests, is also evident in this case, with instability in the allocations obtained by the REIT sector. The increase in allocations as the investment horizons are increased is also observed in the risk reduction tests. Exhibit 5 also shows that the risk reduction benefit from including REITs in the mixedasset portfolios is greater than its return enhancing capabilities. For example, for the five year investment horizon the reduction in portfolio risk at the lower end of the efficient frontier (portfolios 1-5) is between 13 and 7 basis points, twice that compared with its return enhancement for the same portfolios. For the twenty-year holding periods this ratio is even greater for the middle level portfolios (611), with the reduction in risk is almost three times that as for the gain in return.

In comparing the return enhancement and risk reduction tests a key issue relates to the allocations obtained in each case. If the average allocations for the twenty portfolios are compared it is evident that at the low risk/return portfolios higher allocations are obtained in the return enhancement cases, 
however, this trend reverses at the higher end of the frontier. This would support the findings reported earlier. In the lower risk/return portfolios REITs are obtaining allocations at the expense of fixed income securities. Given the low level of risk that this sector has, REITs 'competitive advantage' is in the higher returns obtained. As noted from Exhibit 1, while REITs do have higher standard deviations than bonds, the return enhancement is substantial. In addition, in comparison to stocks, REITs are lower risk while still providing return enhancement. In contrast, towards the high end of the frontier, REITs are competing with equities, against which they are a relatively low risk/return asset. In this case, the benefit from holding REITs comes from the sectors risk reduction qualities. REITs obtain this allocation due to their lower risk levels compared to stocks. While the average returns are also lower, they are not as low as bonds. In addition, the low correlation coefficients generally found between stocks and REITs also will come into play in this case. Therefore, the asset appeals across much of the frontier but for different reasons, but with the diversification potential of the sector underlying both. These trends can also be seen from Exhibit 6 . Exhibit 6 displays the differential allocation in REITs, measured as the allocation in the return enhancement case minus that in the risk reduction scenario. A positive figure indicates that on average the allocation in the return enhancing case is more. It can be seen that apart from one exception all of the differential allocation figures are positive up until portfolio 12, after which they are largely negative. This illustrates that in the lower section of the efficient frontier allocations are greater in the return enhancement scenario and that this reverses at the higher end of the frontier. The Exhibit also displays the ratio of the return enhancement benefits to the absolute risk reduction figure. It can be seen that this figure largely falls as one moves along the frontier, again indicating that risk reduction become more important the higher up the efficient frontier an investor moves.

$\{$ Insert Exhibit 6\}

\section{5: Conclusion}

This study has examined the attractiveness of REITs in the context of a capital market mixed-asset portfolio. REITs are added to mixed-asset portfolios, firstly holding the risk of the portfolios constant, and secondly the portfolio return constant. The results highlight a number of issues in relation to the role of REITs within a mixed-asset framework. First, across four different investment horizons, and on a rolling basis, REITs consistently provide diversification benefits to the mixed-asset portfolio, with substantial allocations in the efficient portfolios. Secondly, these benefits tend to increase as the investment horizon is extended, indicating that REITs may be more attractive to investors with longer holding periods. This increased attractiveness over longer holding periods may also be due to some of the factors highlighted in the literature review and that the linkages between REITs and the private real estate market increase with the use of longer horizons. Therefore, over these longer investment 
periods, REITs may be displaying more of the diversification qualities of the direct market, further enhancing their diversification qualities.

Finally, the benefits of REITs appear to come from both its return enhancement and risk reduction benefits. In the low risk/return portfolios the allocations obtained in the return enhancement tests are larger than those when examining risk reduction. This trend however, reverses as one moves up the efficient frontier. This would indicate that as an investor moves along the frontier the rationale behind the inclusion of REITs alters, with increasing emphasis being placed on the assets risk reduction qualities rather than its return enhancing capabilities. This trend probably arises from two key issues. Firstly, the low correlations relative to both asset classes. While REITs have lower correlations with the general equity indices examined, this is not at the expense of increased coefficients with regard to bonds. Secondly, as noted in the paper, REITs effectively sit between the broad equity and fixedincome sectors, with both risk and return measures in-between stocks and bonds. This enables REITs to appear return enhancing to bonds, without the same degree of increased risk that would be seen with stocks, and also risk reducing to stocks. In the case of stocks they provide diversification benefits due to their relative low risk measures and correlation coefficients, without the same level of return sacrifice that would occur if funds were switched into the fixed-income market. 


\section{References}

Barkham, R. \& Geltner, D. (1995). Price Discovery in American and British Property Markets, Real Estate Economics, 23, 21-44.

Campeau, F. (1994) A Microstructure Analysis of the Information on Securitized and Unsecuritized Commercial Real Estate Markets, Cambridge University Phd

Chiang, K.C.H. and Lee, Ming-Long (2002) REITs in the Decentralized Investment Industry, Journal of Property Investment \& Finance, 20, 496-512

Chopra, V.K. (1993) Mean-Variance Revisited: Near Optimal Portfolios and Sensitivity to Input Variations, Journal of Investing.

Chopra, V.K. and Ziemba, W.T. (1993) The Effect of Errors in Means, Variances and Covariances on Optimal Portfolio Choice, Journal of Portfolio Management, Winter, 6-11.

Chow, G., Jacquier E., Kritzman M. and Lowry K. (1999) Optimal Portfolios in Good and Times Bad, Financial Analysts Journal, May/June, 65-73

Ciochetti, B.A., Craft, T.M. and Shilling, J.D. (2002) Institutional Investors' Preferences for REIT Stocks, Real Estate Economics, 30, 567-594

Clayton, J and MacKinnon, G. (2000) What Drives Equity REIT Returns: The Relative Influences of Bonds, Stocks and Real Estate Factors, Paper presented at the American Real Estate and Urban Economics Association meeting, Boston

Clayton, J and MacKinnon, G. (2001) The Time-Varying Nature of the Link between REIT, Real Estate and Financial Returns, Journal of Real Estate Portfolio Management, 7, 43-54.

Corgel, J.G., McIntosh, W. and Ott, S.H. (1995) Real Estate Investment Trusts: A Review of the Financial Economic Literature, Journal of Real Estate Literature, 3, 1 13-43

Feldman, B.E. (2003) Investment Policy for Securitized and Direct Real Estate, Journal of Portfolio Management, Special Real Estate Issue, 112-121

Frost, P.A. and Savarino, J.E. (1988) For Better Performance: Constrain Portfolio Weights, Journal of Portfolio Management, Fall, 29-34.

Glascock, J.L., Lu, C. and So, R.W. (2000) Further Evidence on the Integration of REIT, Bond, and Stock Returns, Journal of Real Estate Finance and Economics, 20, 1-9

Gyourko, J. and Kiem, D. (1992) What Does the Stock Market Tell us about Real Estate Returns, Journal of the American Real Estate and Urban Economics Association, 20, 457-485

Hansen, L.P. and Jagannathan, R. (1991) Implications of Security Market Data for Models of Dynamic Economics, Journal of Political Economy, 99, 225-261.

Hoesli, M., Lekander, J. \& Witkiewicz, W. (2004). International Evidence on Real Estate as a Portfolio Diversifier, Journal of Real Estate Research, 26, 161-206.

Jorion, P. (1992) Portfolio Optimisation in Practice, Financial Analysts Journal, January-February, 68-74

Kuhle, J. (1987) Portfolio Diversification and Return benefit - Common Stocks Vs. Real Estate Investment Trusts (REITs), The Journal of Real Estate Research, 2, 1-9 
Li, Y. and Wang, K. (1995) The Predictability of REIT Returns and Market Segmentation, Journal of Real Estate Research, 10, 471-482

Liang, Y. and McIntosh, W. (1998) REIT Style and Performance, Journal of Real Estate Portfolio Management, 4, 69-78

Liang, Y. and Naranjo (1999) (1999) The Integration of Commercial Real Estate Markets and Stock markets, Real Estate Economics, 27, 483-515

Markowitz, H. M. (1952) Portfolio Selection, Journal of Finance, 7, 77-91

Michaud, R. O. (1989) The Markowitz Optimisation Enigma: is 'Optimized' Optimal? Financial Analysts Journal, January/February, 31-42

Michaud, R. O. (1998) Efficient Asset Management, Harvard Business School Press, Boston Massachusetts, USA

Mull, S.R. and Soenen, L.A. (1997) US REITs as an Asset Class in International Investment Portfolios, Financial Analysts Journal, 5, 55-61

Mueller, A.G. and Mueller, G.R. (2003) Public and Private Real Estate in the Mixed-Asset Portfolio, Journal of Real Estate Portfolio Management, 9, 193-203

Mueller, G.R., Pauley, K.R. and Morrill, W.K. Jr. (1994) Should REITs be Included in a Mixed-Asset Portfolio? Real Estate Finance, 11, 23-28

Myer, F.C. and Webb, J.R. (1993) Return Properties on Equity REITs, Common Stocks and Commercial Real Estate: A Comparison, Journal of Real Estate Research, 8, 87-106

NAREIT (2002) Diversification Benefits of REITs - An Analysis by Ibbotson Associates, $\mathrm{html} / / \mathrm{www}$. nareit.com

Oppenheimer, P. and Grissom, T.V. (1998) Frequency Space Correlation between REITs and Capital Market Indices, Journal of Real Estate Research, 16, 291-309

Sanders, A.B. (1998) The Historical Behavior of REIT Returns,: A Capital Market Perspective, in Garrigan, R.T. and Parsons, J.F.C. (eds.), Real Estate Investment Trusts, McGraw-Hill

Sharpe, W., F. (1988) Determining A Fund's Effective Asset Mix, Investment Management Review, November/December, 59-69.

Sharpe, W., F. (1992) Asset Allocation: Management Style and Performance Measurement, The Journal of Portfolio Management, Winter, 7-19

Stevenson, S. (2000) Constraining Optimal Portfolios and The Effect on Real Estates Allocation, Journal of Property Investment \& Finance, 18, 488-506

Stevenson, S. (2001a). Bayes-Stein Estimators and International Real Estate Asset Allocation, Journal of Real Estate Research, 21, 89-103.

Stevenson, S. (2001b). The Long-Term Advantages of Incorporating Indirect Securities in Direct Real Estate Portfolios, Journal of Real Estate Portfolio Management, 7, 5-16.

Stevenson, S. (2001c) Evaluating the Investment Attributes and Performance of Property Companies, Journal of Property Investment \& Finance, 19, 251-266 
Stevenson, S. (2002). An Examination of Volatility Spillovers in REIT Returns, Journal of Real Estate Portfolio Management, 8, 229-238.

Ziering, B. Liang, D.C. and Mclntosh, W. (1999) REIT Correlations with Capital market Indexes: Separating Signal from Noise, Real Estate Finance, 15, 61-67

Zietz, E.M., Sirmans, G.S. and Friday, H.S. (2003) The Environment and Performance of Real Estate Investment Trusts, Journal of Real Estate Portfolio Management, 9, 127-165 


\section{Exhibits}

Exhibit 1: Summary Statistics over Entire Sample Period

\begin{tabular}{|c|c|c|c|c|c|c|c|c|c|c|c|c|c|c|c|}
\hline & REITS & $\begin{array}{c}\text { S\&P } 500 \\
\text { Composite }\end{array}$ & $\begin{array}{c}\text { Wilshire } \\
\text { Mid-Cap } \\
\text { Value }\end{array}$ & $\begin{array}{l}\text { Wilshire } \\
\text { Mid-Cap } \\
\text { Growth }\end{array}$ & $\begin{array}{l}\text { Wilshire } \\
\text { Small-Cap } \\
\text { Value }\end{array}$ & $\begin{array}{l}\text { Wilshire } \\
\text { Small-Cap } \\
\text { Growth }\end{array}$ & $\begin{array}{l}\text { Wilsihre } \\
\text { Micro-Cap }\end{array}$ & $\begin{array}{c}\text { Treasury } \\
\text { Bill } \\
\end{array}$ & $\begin{array}{c}\text { Gov't } \\
\text { Bonds 1-3 } \\
\text { yrs }\end{array}$ & $\begin{array}{c}\text { Gov't } \\
\text { Bonds 3-5 } \\
\text { yrs }\end{array}$ & $\begin{array}{c}\text { Gov't } \\
\text { Bonds 5-7 } \\
\text { yrs }\end{array}$ & $\begin{array}{c}\text { Gov't } \\
\text { Bonds 7- } \\
10 \text { yrs } \\
\end{array}$ & $\begin{array}{c}\text { Gov't } \\
\text { Bonds } 10+ \\
\text { yrs }\end{array}$ & $\begin{array}{c}\text { Asian } \\
\text { Equities }\end{array}$ & $\begin{array}{c}\text { European } \\
\text { Equities }\end{array}$ \\
\hline \multicolumn{16}{|l|}{ Panel A: Summary Statistics } \\
\hline Average Monthly Return & 0.9875 & 1.2629 & 1.2893 & 1.2250 & 1.3305 & 1.0503 & 1.2598 & 0.5228 & 0.0274 & 0.0877 & 0.1020 & 0.1360 & 0.2095 & 0.9768 & 1.1170 \\
\hline Standard Deviation & 3.5737 & 4.3328 & 4.7617 & 6.2403 & 4.9209 & 6.6795 & 6.2462 & 0.2571 & 0.8864 & 1.5465 & 2.0519 & 2.4588 & 3.3430 & 6.4952 & 4.8016 \\
\hline Variance & 12.7712 & 18.7736 & 22.6733 & 38.9419 & 24.2149 & 44.6157 & 39.0151 & 0.0661 & 0.7857 & 2.3915 & 4.2102 & 6.0458 & 11.1758 & 42.1873 & 23.0549 \\
\hline \multicolumn{16}{|l|}{ Panel B: Correlation Matrix } \\
\hline REITS & 1.0000 & & & & & & & & & & & & & & \\
\hline S\&P 500 Composite & 0.4524 & 1.0000 & & & & & & & & & & & & & \\
\hline Wilshire Mid-Cap Value & 0.6741 & 0.7859 & 1.0000 & & & & & & & & & & & & \\
\hline Wilshire Mid-Cap Growth & 0.4832 & 0.8129 & 0.7489 & 1.0000 & & & & & & & & & & & \\
\hline Wilshire Small-Cap Value & 0.7060 & 0.7475 & 0.9726 & 0.7708 & 1.0000 & & & & & & & & & & \\
\hline Wilshire Small-Cap Growth & 0.5084 & 0.7725 & 0.7366 & 0.9791 & 0.7845 & 1.0000 & & & & & & & & & \\
\hline Wilsihre Micro-Cap & 0.5537 & 0.6324 & 0.6920 & 0.8532 & 0.7744 & 0.9009 & 1.0000 & & & & & & & & \\
\hline US Treasury Bill & -0.0304 & 0.0039 & -0.0440 & -0.0343 & -0.0347 & -0.0426 & -0.1067 & 1.0000 & & & & & & & \\
\hline US Gov't Bonds 1-3 yrs & 0.1801 & 0.1265 & 0.1006 & 0.0337 & 0.0523 & 0.0093 & -0.0452 & 0.1568 & 1.0000 & & & & & & \\
\hline US Gov't Bonds 3-5 yrs & 0.1770 & 0.1406 & 0.0952 & 0.0312 & 0.0410 & 0.0013 & -0.0579 & 0.0913 & 0.9594 & 1.0000 & & & & & \\
\hline US Gov't Bonds 5-7 yrs & 0.1692 & 0.1465 & 0.1063 & 0.0385 & 0.0511 & 0.0071 & -0.0584 & 0.0696 & 0.9277 & 0.9877 & 1.0000 & & & & \\
\hline US Gov't Bonds 7-10 yrs & 0.1746 & 0.1619 & 0.1240 & 0.0516 & 0.0688 & 0.0183 & -0.0497 & 0.0547 & 0.8876 & 0.9686 & 0.9891 & 1.0000 & & & \\
\hline US Gov't Bonds 10+ yrs & 0.1966 & 0.2038 & 0.1725 & 0.0887 & 0.1194 & 0.0551 & -0.0075 & 0.0523 & 0.8179 & 0.9087 & 0.9426 & 0.9723 & 1.0000 & & \\
\hline Asian Equities (DS) & 0.1708 & 0.3660 & 0.3089 & 0.3716 & 0.2949 & 0.3647 & 0.3074 & -0.0220 & 0.0689 & 0.0650 & 0.0586 & 0.0465 & 0.0465 & 1.0000 & \\
\hline European Equities (DS) & 0.3817 & 0.6471 & 0.5661 & 0.6120 & 0.5592 & 0.5903 & 0.5060 & -0.0507 & 0.1159 & 0.1202 & 0.1180 & 0.1276 & 0.1605 & 0.5478 & 1.0000 \\
\hline
\end{tabular}


Exhibit 2: Percentage of the Time When REITs Achieved a Positive Allocation and Reached Their Upper Bound (Enhancing Returns)

\begin{tabular}{|c|c|c|c|c|c|c|c|c|}
\hline & \multicolumn{4}{|c|}{$\begin{array}{l}\text { Percentage of the Time When REITs } \\
\text { Achieved a Positive Allocation }\end{array}$} & \multicolumn{4}{|c|}{$\begin{array}{l}\text { Percentage of the Time when REITs } \\
\text { Reached their Upper Bound }\end{array}$} \\
\hline & 5-year & 10-year & 15-year & 20-year & 5-year & 10-year & 15-year & 20-year \\
\hline 1 & $100 \%$ & $93 \%$ & $100 \%$ & $100 \%$ & $0 \%$ & $21 \%$ & $11 \%$ & $50 \%$ \\
\hline 2 & $100 \%$ & $100 \%$ & $100 \%$ & $100 \%$ & $0 \%$ & $21 \%$ & $11 \%$ & $50 \%$ \\
\hline 3 & $95 \%$ & $100 \%$ & $100 \%$ & $100 \%$ & $5 \%$ & $21 \%$ & $22 \%$ & $50 \%$ \\
\hline 4 & $95 \%$ & $100 \%$ & $100 \%$ & $100 \%$ & $5 \%$ & $21 \%$ & $22 \%$ & $75 \%$ \\
\hline 5 & $84 \%$ & $100 \%$ & $100 \%$ & $100 \%$ & $5 \%$ & $21 \%$ & $22 \%$ & $75 \%$ \\
\hline 6 & $79 \%$ & $100 \%$ & $100 \%$ & $100 \%$ & $11 \%$ & $21 \%$ & $33 \%$ & $75 \%$ \\
\hline 7 & $79 \%$ & $100 \%$ & $100 \%$ & $100 \%$ & $21 \%$ & $21 \%$ & $44 \%$ & $75 \%$ \\
\hline 8 & $79 \%$ & $100 \%$ & $100 \%$ & $100 \%$ & $26 \%$ & $21 \%$ & $44 \%$ & $75 \%$ \\
\hline 9 & $79 \%$ & $100 \%$ & $100 \%$ & $100 \%$ & $26 \%$ & $29 \%$ & $44 \%$ & $75 \%$ \\
\hline 10 & $79 \%$ & $100 \%$ & $89 \%$ & $100 \%$ & $26 \%$ & $29 \%$ & $44 \%$ & $75 \%$ \\
\hline 11 & $74 \%$ & $100 \%$ & $89 \%$ & $100 \%$ & $32 \%$ & $29 \%$ & $44 \%$ & $75 \%$ \\
\hline 12 & $74 \%$ & $100 \%$ & $89 \%$ & $100 \%$ & $32 \%$ & $36 \%$ & $56 \%$ & $50 \%$ \\
\hline 13 & $74 \%$ & $100 \%$ & $89 \%$ & $100 \%$ & $37 \%$ & $29 \%$ & $56 \%$ & $50 \%$ \\
\hline 14 & $74 \%$ & $100 \%$ & $89 \%$ & $100 \%$ & $26 \%$ & $21 \%$ & $11 \%$ & $0 \%$ \\
\hline 15 & $74 \%$ & $100 \%$ & $89 \%$ & $100 \%$ & $16 \%$ & $7 \%$ & $0 \%$ & $0 \%$ \\
\hline 16 & $74 \%$ & $100 \%$ & $89 \%$ & $100 \%$ & $5 \%$ & $0 \%$ & $0 \%$ & $0 \%$ \\
\hline 17 & $68 \%$ & $100 \%$ & $89 \%$ & $100 \%$ & $5 \%$ & $0 \%$ & $0 \%$ & $0 \%$ \\
\hline 18 & $63 \%$ & $86 \%$ & $89 \%$ & $50 \%$ & $5 \%$ & $0 \%$ & $0 \%$ & $0 \%$ \\
\hline 19 & $47 \%$ & $29 \%$ & $44 \%$ & $25 \%$ & $0 \%$ & $0 \%$ & $0 \%$ & $0 \%$ \\
\hline 20 & $0 \%$ & $0 \%$ & $0 \%$ & $0 \%$ & $0 \%$ & $0 \%$ & $0 \%$ & $0 \%$ \\
\hline
\end{tabular}

Exhibit 3: Percentage of the Time When REITs Achieved a Positive Allocation and Reached Their Upper Bound (Reducing Risk)

\begin{tabular}{|c|c|c|c|c|c|c|c|c|}
\hline & \multicolumn{4}{|c|}{$\begin{array}{l}\text { Percentage of the Time When REITs } \\
\text { Achieved a Positive Allocation }\end{array}$} & \multicolumn{4}{|c|}{$\begin{array}{l}\text { Percentage of the Time when REITs } \\
\text { Reached their Upper Bound }\end{array}$} \\
\hline & 5-year & 10-year & 15-year & 20-year & 5-year & 10-year & 15-year & 20-year \\
\hline 1 & $100 \%$ & $93 \%$ & $100 \%$ & $100 \%$ & $0 \%$ & $7 \%$ & $11 \%$ & $0 \%$ \\
\hline 2 & $100 \%$ & $93 \%$ & $100 \%$ & $100 \%$ & $0 \%$ & $14 \%$ & $11 \%$ & $25 \%$ \\
\hline 3 & $95 \%$ & $93 \%$ & $100 \%$ & $100 \%$ & $0 \%$ & $14 \%$ & $11 \%$ & $50 \%$ \\
\hline 4 & $95 \%$ & $93 \%$ & $100 \%$ & $100 \%$ & $5 \%$ & $14 \%$ & $22 \%$ & $50 \%$ \\
\hline 5 & $84 \%$ & $93 \%$ & $100 \%$ & $100 \%$ & $5 \%$ & $14 \%$ & $22 \%$ & $75 \%$ \\
\hline 6 & $79 \%$ & $93 \%$ & $100 \%$ & $100 \%$ & $5 \%$ & $14 \%$ & $22 \%$ & $75 \%$ \\
\hline 7 & $79 \%$ & $93 \%$ & $100 \%$ & $100 \%$ & $11 \%$ & $14 \%$ & $22 \%$ & $75 \%$ \\
\hline 8 & $79 \%$ & $93 \%$ & $100 \%$ & $100 \%$ & $16 \%$ & $14 \%$ & $33 \%$ & $75 \%$ \\
\hline 9 & $79 \%$ & $93 \%$ & $100 \%$ & $100 \%$ & $21 \%$ & $14 \%$ & $44 \%$ & $75 \%$ \\
\hline 10 & $79 \%$ & $93 \%$ & $100 \%$ & $100 \%$ & $26 \%$ & $21 \%$ & $44 \%$ & $75 \%$ \\
\hline 11 & $74 \%$ & $93 \%$ & $100 \%$ & $100 \%$ & $26 \%$ & $21 \%$ & $44 \%$ & $75 \%$ \\
\hline 12 & $74 \%$ & $93 \%$ & $100 \%$ & $100 \%$ & $32 \%$ & $21 \%$ & $44 \%$ & $75 \%$ \\
\hline 13 & $74 \%$ & $93 \%$ & $100 \%$ & $100 \%$ & $37 \%$ & $29 \%$ & $67 \%$ & $75 \%$ \\
\hline 14 & $74 \%$ & $93 \%$ & $100 \%$ & $100 \%$ & $32 \%$ & $21 \%$ & $56 \%$ & $50 \%$ \\
\hline 15 & $74 \%$ & $93 \%$ & $100 \%$ & $100 \%$ & $37 \%$ & $21 \%$ & $11 \%$ & $25 \%$ \\
\hline 16 & $74 \%$ & $93 \%$ & $100 \%$ & $100 \%$ & $32 \%$ & $7 \%$ & $11 \%$ & $0 \%$ \\
\hline 17 & $68 \%$ & $93 \%$ & $100 \%$ & $100 \%$ & $11 \%$ & $0 \%$ & $0 \%$ & $0 \%$ \\
\hline 18 & $63 \%$ & $79 \%$ & $100 \%$ & $50 \%$ & $5 \%$ & $0 \%$ & $0 \%$ & $0 \%$ \\
\hline 19 & $47 \%$ & $29 \%$ & $56 \%$ & $25 \%$ & $5 \%$ & $0 \%$ & $0 \%$ & $0 \%$ \\
\hline 20 & $0 \%$ & $0 \%$ & $0 \%$ & $0 \%$ & $0 \%$ & $0 \%$ & $0 \%$ & $0 \%$ \\
\hline
\end{tabular}


Exhibit 4: Summary Aggregate Return Enhancement Results

\begin{tabular}{rcccccccc}
\hline \multicolumn{3}{c}{ REIT Allocation } & \multicolumn{4}{c}{ Average Return Enhancement } \\
\hline 1 & $\mathbf{5}$ year & $\mathbf{1 0}$ year & $\mathbf{1 5}$ year & $\mathbf{2 0}$ year & $\mathbf{5}$ year & $\mathbf{1 0}$ year & $\mathbf{1 5}$ year & $\mathbf{2 0}$ year \\
\hline 2 & $9.46 \%$ & $11.32 \%$ & $13.70 \%$ & $16.25 \%$ & 0.0759 & 0.0525 & 0.0463 & 0.0420 \\
3 & $9.50 \%$ & $12.03 \%$ & $14.08 \%$ & $16.58 \%$ & 0.0547 & 0.0376 & 0.0315 & 0.0326 \\
4 & $9.68 \%$ & $12.07 \%$ & $14.56 \%$ & $17.00 \%$ & 0.0436 & 0.0312 & 0.0251 & 0.0315 \\
5 & $9.79 \%$ & $12.20 \%$ & $15.01 \%$ & $17.36 \%$ & 0.0381 & 0.0283 & 0.0230 & 0.0316 \\
6 & $10.05 \%$ & $11.88 \%$ & $15.45 \%$ & $17.63 \%$ & 0.0364 & 0.0261 & 0.0219 & 0.0319 \\
7 & $10.26 \%$ & $11.66 \%$ & $15.83 \%$ & $17.52 \%$ & 0.0341 & 0.0242 & 0.0218 & 0.0323 \\
8 & $10.53 \%$ & $11.98 \%$ & $15.72 \%$ & $17.67 \%$ & 0.0312 & 0.0224 & 0.0220 & 0.0327 \\
9 & $10.74 \%$ & $12.35 \%$ & $15.81 \%$ & $17.75 \%$ & 0.0265 & 0.0210 & 0.0222 & 0.0330 \\
10 & $10.89 \%$ & $12.59 \%$ & $16.03 \%$ & $17.83 \%$ & 0.0247 & 0.0208 & 0.0225 & 0.0335 \\
11 & $11.04 \%$ & $12.81 \%$ & $16.26 \%$ & $17.90 \%$ & 0.0238 & 0.0209 & 0.0234 & 0.0339 \\
12 & $11.14 \%$ & $13.03 \%$ & $16.42 \%$ & $17.81 \%$ & 0.0237 & 0.0211 & 0.0238 & 0.0343 \\
13 & $11.03 \%$ & $13.00 \%$ & $16.03 \%$ & $16.93 \%$ & 0.0236 & 0.0210 & 0.0238 & 0.0322 \\
14 & $10.87 \%$ & $12.24 \%$ & $14.11 \%$ & $15.48 \%$ & 0.0230 & 0.0195 & 0.0222 & 0.0277 \\
15 & $10.12 \%$ & $10.89 \%$ & $11.48 \%$ & $12.35 \%$ & 0.0207 & 0.0164 & 0.0189 & 0.0222 \\
16 & $8.75 \%$ & $8.75 \%$ & $8.91 \%$ & $8.58 \%$ & 0.0169 & 0.0122 & 0.0145 & 0.0157 \\
17 & $6.93 \%$ & $5.87 \%$ & $6.06 \%$ & $4.95 \%$ & 0.0118 & 0.0074 & 0.0094 & 0.0085 \\
18 & $4.98 \%$ & $2.63 \%$ & $3.14 \%$ & $1.80 \%$ & 0.0070 & 0.0027 & 0.0039 & 0.0029 \\
19 & $2.35 \%$ & $0.15 \%$ & $0.46 \%$ & $0.25 \%$ & 0.0025 & 0.0001 & 0.0009 & 0.0003 \\
20 & $0.00 \%$ & $0.00 \%$ & $0.00 \%$ & $0.00 \%$ & 0.0000 & 0.0000 & 0.0000 & 0.0000 \\
\hline
\end{tabular}

Exhibit 5: Summary Aggregate Risk Reduction Results

\begin{tabular}{ccccccccc}
\hline & \multicolumn{3}{c}{ REIT Allocation } & \multicolumn{4}{c}{ Average Risk Reduction } \\
\hline & 5 year & 10 year & 15 year & 20 year & 5 year & 10 year & 15 year & 20 year \\
\hline 1 & $10.35 \%$ & $10.88 \%$ & $12.80 \%$ & $15.28 \%$ & -0.1340 & -0.1166 & -0.1147 & -0.1060 \\
2 & $9.43 \%$ & $10.58 \%$ & $13.50 \%$ & $16.08 \%$ & -0.1042 & -0.0851 & -0.0799 & -0.0843 \\
3 & $9.09 \%$ & $10.60 \%$ & $14.06 \%$ & $16.63 \%$ & -0.0872 & -0.0754 & -0.0641 & -0.0833 \\
4 & $9.25 \%$ & $10.71 \%$ & $14.53 \%$ & $17.05 \%$ & -0.0785 & -0.0709 & -0.0589 & -0.0858 \\
5 & $9.33 \%$ & $10.83 \%$ & $14.95 \%$ & $17.42 \%$ & -0.0732 & -0.0662 & -0.0563 & -0.0887 \\
6 & $9.66 \%$ & $10.52 \%$ & $15.24 \%$ & $17.49 \%$ & -0.0673 & -0.0626 & -0.0570 & -0.0912 \\
7 & $9.96 \%$ & $10.12 \%$ & $15.54 \%$ & $17.57 \%$ & -0.0608 & -0.0596 & -0.0579 & -0.0932 \\
8 & $10.04 \%$ & $10.34 \%$ & $15.60 \%$ & $17.65 \%$ & -0.0563 & -0.0564 & -0.0593 & -0.0948 \\
9 & $10.06 \%$ & $10.75 \%$ & $15.71 \%$ & $17.73 \%$ & -0.0539 & -0.0557 & -0.0610 & -0.0965 \\
10 & $10.29 \%$ & $11.08 \%$ & $15.93 \%$ & $17.80 \%$ & -0.0503 & -0.0569 & -0.0625 & -0.0981 \\
11 & $10.71 \%$ & $11.30 \%$ & $16.14 \%$ & $17.88 \%$ & -0.0490 & -0.0581 & -0.0641 & -0.0997 \\
12 & $11.10 \%$ & $11.52 \%$ & $16.36 \%$ & $17.96 \%$ & -0.0501 & -0.0593 & -0.0656 & -0.1012 \\
13 & $11.13 \%$ & $11.69 \%$ & $16.39 \%$ & $18.03 \%$ & -0.0511 & -0.0605 & -0.0670 & -0.1027 \\
14 & $11.09 \%$ & $11.55 \%$ & $15.74 \%$ & $17.07 \%$ & -0.0512 & -0.0614 & -0.0677 & -0.0997 \\
15 & $10.89 \%$ & $10.84 \%$ & $13.96 \%$ & $15.60 \%$ & -0.0506 & -0.0609 & -0.0642 & -0.0898 \\
16 & $10.03 \%$ & $9.22 \%$ & $11.10 \%$ & $12.08 \%$ & -0.0475 & -0.0550 & -0.0551 & -0.0706 \\
17 & $8.08 \%$ & $6.08 \%$ & $7.88 \%$ & $6.90 \%$ & -0.0369 & -0.0425 & -0.0402 & -0.0422 \\
18 & $5.75 \%$ & $2.45 \%$ & $4.01 \%$ & $2.54 \%$ & -0.0248 & -0.0158 & -0.0190 & -0.0172 \\
19 & $3.00 \%$ & $0.18 \%$ & $0.72 \%$ & $0.33 \%$ & -0.0121 & -0.0003 & -0.0052 & -0.0020 \\
20 & $0.00 \%$ & $0.00 \%$ & $0.00 \%$ & $0.00 \%$ & 0.0000 & 0.0000 & 0.0000 & 0.0000 \\
\hline
\end{tabular}


Exhibit 6: Variation in Allocations and Benefits

\begin{tabular}{ccccccccc}
\hline & \multicolumn{3}{c}{ Differential REIT Allocation } & \multicolumn{3}{c}{ Return } & Enhancement/Absolute Risk \\
Reduction Ratio & \\
\hline & 5 year & 10 year & 15 year & 20 year & 5 year & 10 year & 15 year & 20 year \\
\hline 1 & $-0.89 \%$ & $0.44 \%$ & $0.90 \%$ & $0.97 \%$ & 0.5664 & 0.4503 & 0.4037 & 0.3962 \\
2 & $0.07 \%$ & $1.45 \%$ & $0.58 \%$ & $0.50 \%$ & 0.5250 & 0.4418 & 0.3942 & 0.3867 \\
3 & $0.50 \%$ & $1.47 \%$ & $0.50 \%$ & $0.37 \%$ & 0.5000 & 0.4138 & 0.3916 & 0.3782 \\
4 & $0.43 \%$ & $1.49 \%$ & $0.48 \%$ & $0.31 \%$ & 0.4854 & 0.3992 & 0.3905 & 0.3683 \\
5 & $0.46 \%$ & $1.29 \%$ & $0.50 \%$ & $0.02 \%$ & 0.4973 & 0.3943 & 0.3890 & 0.3596 \\
6 & $0.39 \%$ & $1.36 \%$ & $0.39 \%$ & $0.03 \%$ & 0.5067 & 0.3866 & 0.3825 & 0.3542 \\
7 & $0.30 \%$ & $1.54 \%$ & $0.29 \%$ & $0.02 \%$ & 0.5132 & 0.3758 & 0.3800 & 0.3509 \\
8 & $0.49 \%$ & $1.64 \%$ & $0.12 \%$ & $0.02 \%$ & 0.5133 & 0.3723 & 0.3744 & 0.3481 \\
9 & $0.68 \%$ & $1.60 \%$ & $0.10 \%$ & $0.02 \%$ & 0.4917 & 0.3680 & 0.3689 & 0.3472 \\
10 & $0.60 \%$ & $1.51 \%$ & $0.10 \%$ & $0.03 \%$ & 0.4911 & 0.3656 & 0.3664 & 0.3456 \\
11 & $0.33 \%$ & $1.51 \%$ & $0.12 \%$ & $0.02 \%$ & 0.4857 & 0.3597 & 0.3651 & 0.3440 \\
12 & $0.04 \%$ & $1.51 \%$ & $0.06 \%$ & $-0.15 \%$ & 0.4731 & 0.3558 & 0.3628 & 0.3389 \\
13 & $-0.10 \%$ & $1.31 \%$ & $-0.36 \%$ & $-1.10 \%$ & 0.4618 & 0.3471 & 0.3552 & 0.3135 \\
14 & $-0.22 \%$ & $0.69 \%$ & $-1.63 \%$ & $-1.59 \%$ & 0.4492 & 0.3176 & 0.3279 & 0.2778 \\
15 & $-0.77 \%$ & $0.05 \%$ & $-2.48 \%$ & $-3.25 \%$ & 0.4091 & 0.2693 & 0.2944 & 0.2472 \\
16 & $-1.28 \%$ & $-0.47 \%$ & $-2.19 \%$ & $-3.50 \%$ & 0.3558 & 0.2218 & 0.2632 & 0.2224 \\
17 & $-1.15 \%$ & $-0.21 \%$ & $-1.82 \%$ & $-1.95 \%$ & 0.3198 & 0.1741 & 0.2338 & 0.2014 \\
18 & $-0.77 \%$ & $0.18 \%$ & $-0.87 \%$ & $-0.74 \%$ & 0.2823 & 0.1709 & 0.2053 & 0.1686 \\
19 & $-0.65 \%$ & $-0.03 \%$ & $-0.26 \%$ & $-0.08 \%$ & 0.2066 & 0.3333 & 0.1731 & 0.1500 \\
20 & $0.00 \%$ & $0.00 \%$ & $0.00 \%$ & $0.00 \%$ & 0.0000 & 0.0000 & 0.0000 & 0.0000 \\
\hline
\end{tabular}


Appendix: Individual results

Exhibit 1A: Allocations and Level of Return Enhancement for Five Year Time Horizons

\begin{tabular}{|c|c|c|c|c|c|c|c|c|c|c|c|c|c|c|c|c|c|c|c|}
\hline & 1984 & 1985 & 1986 & 1987 & 1988 & 1989 & 1990 & 1991 & 1992 & 1993 & 1994 & 1995 & 1996 & 1997 & 1998 & 1999 & 2000 & 2001 & 2002 \\
\hline \multicolumn{20}{|c|}{ anel A: REIT Allocations } \\
\hline 1 & $14.72 \%$ & $5.94 \%$ & $10.12 \%$ & $10.00 \%$ & $10.00 \%$ & $10.00 \%$ & $2.38 \%$ & $0.92 \%$ & $5.61 \%$ & $5.84 \%$ & $17.09 \%$ & $6.81 \%$ & $13.05 \%$ & $15.82 \%$ & $8.81 \%$ & $3.23 \%$ & $19.28 \%$ & $11.62 \%$ & $8.58 \%$ \\
\hline 2 & $15.04 \%$ & $6.41 \%$ & $11.24 \%$ & $10.00 \%$ & $10.00 \%$ & $10.00 \%$ & $2.26 \%$ & $0.38 \%$ & $5.25 \%$ & $5.58 \%$ & $17.23 \%$ & $6.93 \%$ & $13.21 \%$ & $16.01 \%$ & $8.87 \%$ & $2.28 \%$ & $19.71 \%$ & $11.59 \%$ & $8.48 \%$ \\
\hline 3 & $16.20 \%$ & $6.96 \%$ & $12.64 \%$ & $10.00 \%$ & $10.00 \%$ & $10.00 \%$ & $1.98 \%$ & $0.00 \%$ & $3.96 \%$ & $4.35 \%$ & $17.69 \%$ & $7.18 \%$ & $13.72 \%$ & $16.99 \%$ & $9.04 \%$ & $1.32 \%$ & $20.00 \%$ & $11.61 \%$ & $8.53 \%$ \\
\hline 4 & $17.84 \%$ & $7.52 \%$ & $14.06 \%$ & $10.00 \%$ & $10.00 \%$ & $10.00 \%$ & $1.31 \%$ & $0.00 \%$ & $1.58 \%$ & $2.62 \%$ & $18.32 \%$ & $7.56 \%$ & $14.35 \%$ & $17.98 \%$ & $9.29 \%$ & $1.44 \%$ & $20.00 \%$ & $11.51 \%$ & $8.53 \%$ \\
\hline 5 & $19.95 \%$ & $8.04 \%$ & $15.52 \%$ & $10.00 \%$ & $10.00 \%$ & $10.00 \%$ & $.00 \%$ & $.00 \%$ & $0.00 \%$ & $0.58 \%$ & $18.98 \%$ & $8.03 \%$ & $14.99 \%$ & $18.96 \%$ & $9.66 \%$ & $1.51 \%$ & $20.00 \%$ & $11.32 \%$ & $8.54 \%$ \\
\hline 6 & $20.00 \%$ & $8.52 \%$ & $17.03 \%$ & $11.43 \%$ & $10.00 \%$ & $8.90 \%$ & $0.00 \%$ & $0.00 \%$ & $0.00 \%$ & $0.00 \%$ & $19.63 \%$ & $8.52 \%$ & $15.63 \%$ & $19.91 \%$ & $10.05 \%$ & $1.60 \%$ & $20.00 \%$ & $11.16 \%$ & $8.58 \%$ \\
\hline 7 & $20.00 \%$ & $9.04 \%$ & $18.57 \%$ & $13.49 \%$ & $10.01 \%$ & $7.07 \%$ & $0.00 \%$ & $0.00 \%$ & $0.00 \%$ & $0.00 \%$ & $20.00 \%$ & $8.66 \%$ & $16.27 \%$ & $20.00 \%$ & $10.43 \%$ & $1.75 \%$ & $20.00 \%$ & $10.97 \%$ & $8.70 \%$ \\
\hline 8 & $20.00 \%$ & $9.52 \%$ & $20.00 \%$ & $15.55 \%$ & $11.89 \%$ & $5.22 \%$ & $0.00 \%$ & $0.00 \%$ & $0.00 \%$ & $0.00 \%$ & $20.00 \%$ & $8.87 \%$ & $16.91 \%$ & $20.00 \%$ & $10.81 \%$ & $1.84 \%$ & $20.00 \%$ & $10.78 \%$ & $8.77 \%$ \\
\hline 9 & $20.00 \%$ & $10.08 \%$ & $20.00 \%$ & $17.62 \%$ & $13.70 \%$ & $3.35 \%$ & $0.00 \%$ & $0.00 \%$ & $0.00 \%$ & $0.00 \%$ & $20.00 \%$ & $9.05 \%$ & $17.55 \%$ & $20.00 \%$ & $11.19 \%$ & $1.93 \%$ & $20.00 \%$ & $10.61 \%$ & $8.93 \%$ \\
\hline 10 & $20.00 \%$ & $10.56 \%$ & $20.00 \%$ & $19.70 \%$ & $15.58 \%$ & $1.07 \%$ & $0.00 \%$ & $0.00 \%$ & $0.00 \%$ & $0.00 \%$ & $20.00 \%$ & $9.20 \%$ & $18.19 \%$ & $20.00 \%$ & $11.57 \%$ & $2.03 \%$ & $20.00 \%$ & $9.95 \%$ & $9.07 \%$ \\
\hline 11 & $20.00 \%$ & $11.13 \%$ & $20.00 \%$ & $20.00 \%$ & $18.03 \%$ & $0.00 \%$ & $0.00 \%$ & $0.00 \%$ & $0.00 \%$ & $0.00 \%$ & $20.00 \%$ & $9.38 \%$ & $18.84 \%$ & $20.00 \%$ & $11.95 \%$ & $2.12 \%$ & $20.00 \%$ & $9.15 \%$ & $9.23 \%$ \\
\hline 12 & $20.00 \%$ & $11.61 \%$ & $20.00 \%$ & $20.00 \%$ & $20.00 \%$ & $0.00 \%$ & $0.00 \%$ & $0.00 \%$ & $0.00 \%$ & $0.00 \%$ & $20.00 \%$ & $9.65 \%$ & $19.50 \%$ & $20.00 \%$ & $12.33 \%$ & $2.11 \%$ & $18.93 \%$ & $8.32 \%$ & $9.16 \%$ \\
\hline 13 & $20.00 \%$ & $12.13 \%$ & $20.00 \%$ & $20.00 \%$ & $20.00 \%$ & $0.00 \%$ & $0.00 \%$ & $0.00 \%$ & $0.00 \%$ & $0.00 \%$ & $20.00 \%$ & $9.92 \%$ & $20.00 \%$ & $20.00 \%$ & $12.71 \%$ & $2.17 \%$ & $16.82 \%$ & $7.48 \%$ & $8.36 \%$ \\
\hline 14 & $20.00 \%$ & $12.65 \%$ & $20.00 \%$ & $20.00 \%$ & $20.00 \%$ & $0.00 \%$ & $0.00 \%$ & $0.00 \%$ & $0.00 \%$ & $0.00 \%$ & $19.51 \%$ & $10.51 \%$ & $20.00 \%$ & $19.60 \%$ & $13.10 \%$ & $2.22 \%$ & $14.77 \%$ & $6.64 \%$ & $7.62 \%$ \\
\hline 15 & $20.00 \%$ & $10.63 \%$ & $20.00 \%$ & $19.94 \%$ & $20.00 \%$ & $0.00 \%$ & $0.00 \%$ & $0.00 \%$ & $0.00 \%$ & $0.00 \%$ & $16.54 \%$ & $11.21 \%$ & $18.95 \%$ & $15.24 \%$ & $12.33 \%$ & $2.28 \%$ & $12.47 \%$ & $5.81 \%$ & $6.89 \%$ \\
\hline 16 & $20.00 \%$ & $6.63 \%$ & $18.54 \%$ & $16.12 \%$ & $19.21 \%$ & $0.00 \%$ & $0.00 \%$ & $0.00 \%$ & $0.00 \%$ & $0.00 \%$ & $12.84 \%$ & $11.86 \%$ & $16.80 \%$ & $13.68 \%$ & $9.60 \%$ & $2.33 \%$ & $10.08 \%$ & $2.41 \%$ & $6.15 \%$ \\
\hline 17 & $20.00 \%$ & $2.62 \%$ & $16.89 \%$ & $11.76 \%$ & $14.31 \%$ & $0.00 \%$ & $0.00 \%$ & $0.00 \%$ & $0.00 \%$ & $0.00 \%$ & $8.56 \%$ & $8.07 \%$ & $15.11 \%$ & $12.19 \%$ & $6.68 \%$ & $2.39 \%$ & $7.74 \%$ & $0.00 \%$ & $5.41 \%$ \\
\hline 18 & $20.00 \%$ & $0.00 \%$ & $14.85 \%$ & $7.32 \%$ & $9.58 \%$ & $0.00 \%$ & $0.00 \%$ & $0.00 \%$ & $0.00 \%$ & $0.00 \%$ & $3.93 \%$ & $5.62 \%$ & $10.95 \%$ & $8.23 \%$ & $4.00 \%$ & $0.30 \%$ & $5.25 \%$ & $0.00 \%$ & $4.65 \%$ \\
\hline 19 & $13.10 \%$ & $0.00 \%$ & $7.04 \%$ & $2.99 \%$ & $4.87 \%$ & $0.00 \%$ & $0.00 \%$ & $0.00 \%$ & $0.00 \%$ & $0.00 \%$ & $0.00 \%$ & $2.91 \%$ & $6.40 \%$ & $0.00 \%$ & $1.40 \%$ & $0.00 \%$ & $2.58 \%$ & $0.00 \%$ & $3.46 \%$ \\
\hline 20 & $0.00 \%$ & $0.00 \%$ & $0.00 \%$ & $0.00 \%$ & $0.00 \%$ & $0.00 \%$ & $0.00 \%$ & $0.00 \%$ & $0.00 \%$ & $0.00 \%$ & $0.00 \%$ & $0.00 \%$ & $0.00 \%$ & $0.00 \%$ & $0.00 \%$ & $0.00 \%$ & $0.00 \%$ & $0.00 \%$ & $0.00 \%$ \\
\hline
\end{tabular}




\begin{tabular}{|c|c|c|c|c|c|c|c|c|c|c|c|c|c|c|c|c|c|c|c|}
\hline \multicolumn{20}{|c|}{ anel B: Level of Return Enhancement } \\
\hline 1 & 0.0915 & 0.0087 & 0.0702 & 0.1573 & 0.1458 & 0.1109 & 0.0704 & 0270 & 0.0570 & 0.0374 & 0.0436 & 0.0603 & 0.0687 & 0.0832 & 0.0883 & 0.0575 & 0.0693 & 0.0746 & 0.1203 \\
\hline 2 & 0.0645 & 0.0030 & 0.0602 & 1501 & 0.1388 & 0.0904 & 0.0427 & 0.0058 & 0.0293 & 0.0139 & 0.0275 & 0.0293 & 0.0461 & 0.0569 & 0.0511 & 0.0259 & 0.0544 & 0.0476 & 0.1015 \\
\hline 3 & 0.0518 & 0.0034 & 0.0576 & 1435 & 0.1323 & 0.0807 & 0.0186 & 0.0000 & 0.0100 & 0.0040 & 0.0210 & 0.0104 & 0.0412 & 0.0582 & 0.0273 & 0.0057 & 0.0566 & 0.0233 & 0.0831 \\
\hline 4 & 0.0477 & 0.0037 & 0.0561 & 0.1374 & 0.1263 & 0.0720 & 0.0006 & 0.0000 & 0.0010 & 0.0013 & 0.0220 & 0.0075 & 0.0429 & 0.0598 & & 0.0003 & & 0.0076 & 0.0649 \\
\hline 5 & 0.0521 & 0.0041 & 0.0555 & 1319 & 0.1208 & 0.0634 & 0.0000 & .0000 & 0.0000 & 0.0001 & 0.0229 & 0.0080 & 0.0445 & 0.0612 & 0.0129 & 0.0003 & 0.0606 & 0.0063 & 0.0472 \\
\hline 6 & 0.0543 & 0.0045 & 0.0559 & 0.1186 & 0.1112 & 0.0492 & 0.0000 & 0.0000 & 0.0000 & 0.0000 & 0.0238 & 0.0082 & 0.0462 & 0.0624 & 0.0134 & 0.0004 & 0.0624 & 0.0058 & 0.0307 \\
\hline 7 & 0.0555 & 0.0049 & 0.0578 & 0.1021 & 0.0930 & 0.0352 & 0.0000 & 0.0000 & 0.0000 & 0.0000 & 0.0247 & 0.0081 & 0.0478 & 0.0635 & 0.0139 & 0.0004 & 0.0640 & 0.0054 & 0.0164 \\
\hline 8 & 0.0564 & 0.0052 & 0.0660 & 0.0856 & 0.0741 & 0.0214 & 0.0000 & 0.0000 & 0.0000 & 0.0000 & 0.0256 & 0.0081 & 0.0495 & 0.0647 & 0.0144 & 0.0004 & 0.0655 & 0.0049 & 0.0073 \\
\hline 9 & 0.0573 & 0.0055 & 0.0681 & 0.0692 & 0.0553 & 0.0081 & 0.0000 & 0.0000 & 0.0000 & 0.0000 & 0.0264 & 0.0081 & 0.0512 & 0.0656 & 0.0149 & 0.0005 & 0.0668 & 0.0046 & 0.0026 \\
\hline 10 & 0.0581 & 0.0059 & 0.0701 & 0.0529 & 0.0365 & 0.0006 & 0.0000 & 0.0000 & 0.0000 & 0.0000 & 0.0271 & 0.0079 & 0.0529 & 0.0665 & 0.0154 & 0.0005 & 0.0681 & 0.0041 & 0.0020 \\
\hline 11 & 0.0588 & 0.0063 & 0.0718 & 0.0446 & 0.0228 & 0.0000 & 0.0000 & 0.0000 & 0.0000 & 0.0000 & 0.0278 & 0.0079 & 0.0545 & 0.0674 & 0.0159 & 0.0005 & & 0.0033 & 0.0019 \\
\hline 12 & 0.0596 & 0.0067 & 0.0733 & 0452 & 0.0185 & 0.0000 & 0.0000 & 00 & 0.0000 & 0.0000 & 0.0284 & & 0.0564 & 0.0682 & 0.0164 & 0.0005 & & 0.0025 & 0.0018 \\
\hline 13 & 0.0602 & 0.0072 & 0.0729 & 0456 & 0.0186 & 0.0000 & 0.0000 & 000 & 0.0000 & 0.0000 & 0.0290 & 0.0086 & 0.0585 & 0.0690 & 0.0169 & 0.0005 & 0.0580 & 0.0019 & 0.0015 \\
\hline 14 & 0.0608 & 0.0076 & 0.0678 & 0.0459 & 0.0189 & 0.0000 & 0.0000 & .0000 & 0.0000 & 0.0000 & 0.0274 & 0.0094 & 0.0605 & 0.0680 & 0.0174 & 0.0006 & 0.0501 & 0.0014 & 0.0012 \\
\hline 15 & 0.0612 & 0.0075 & 0.0587 & 0.0436 & 0.0192 & 0.0000 & 0.0000 & 0.0000 & 0.0000 & 0.0000 & 0.0223 & 0.0101 & 0.0581 & 0.0509 & 0.0178 & 0.0006 & 0.0412 & 0.0010 & 0.0009 \\
\hline 16 & 0.0617 & 0.0050 & 0.0461 & 0.0349 & 0.0181 & 0.0000 & 0.0000 & 0.0000 & 0.0000 & 0.0000 & 0.0162 & 0.0110 & 0.0469 & 0.0317 & 0.0162 & 0.0006 & 0.0311 & 0.0005 & 0.0007 \\
\hline 17 & 0.0559 & 0.0009 & 0.0311 & 0.0252 & 0.0143 & 0.0000 & 0.0000 & 0.0000 & 0.0000 & 0.0000 & 0.0090 & 0.0094 & 0.0323 & 0.0120 & 0.0129 & 0.0005 & 0.0205 & 0.0000 & 0.0005 \\
\hline 18 & 0.0409 & 0.0000 & 0.0178 & 0.0149 & 0.0092 & 0.0000 & 0.0000 & & 0.0000 & 0.0000 & 0.0029 & & 0.0176 & 0.0049 & 0.0080 & 0.0001 & 0.0115 & 0.0000 & 0.0003 \\
\hline 19 & 0.0194 & 0.0000 & 0.0064 & 0.0040 & 0.0041 & 0.0000 & 0.0000 & 0.0000 & 0.0000 & 0.0000 & 0.0000 & 0.0012 & 0.0063 & 0.0000 & 0.0019 & 0.0001 & 0.0044 & 0.0000 & 0.0002 \\
\hline 20 & 0.0000 & 0.0000 & 0.0000 & 0.0000 & 0.0000 & 0.0000 & 0.0000 & 0.0000 & 0.0000 & 0.0000 & 0.0000 & 0.0000 & 0.0000 & 0.0000 & 0.0000 & 0.0000 & 0.0000 & 0.0000 & 0.0000 \\
\hline
\end{tabular}


Exhibit 2A: Allocations and Level of Return Enhancement for Ten Year Time Horizons

\begin{tabular}{|c|c|c|c|c|c|c|c|c|c|c|c|c|c|c|}
\hline & 1989 & 1990 & 1991 & 1992 & 1993 & 1994 & 1995 & 1996 & 1997 & 1998 & 1999 & 2000 & 2001 & 2002 \\
\hline \multicolumn{15}{|c|}{ Panel A: REIT Allocations } \\
\hline 1 & $10.00 \%$ & $10.00 \%$ & $10.00 \%$ & $10.00 \%$ & $0.00 \%$ & $10.00 \%$ & $7.88 \%$ & $13.89 \%$ & $15.14 \%$ & $5.45 \%$ & $6.13 \%$ & $20.00 \%$ & $20.00 \%$ & $20.00 \%$ \\
\hline 2 & $10.00 \%$ & $10.00 \%$ & $10.00 \%$ & $10.00 \%$ & $10.00 \%$ & $10.00 \%$ & $7.53 \%$ & $14.05 \%$ & $15.20 \%$ & $5.47 \%$ & $6.19 \%$ & $20.00 \%$ & $20.00 \%$ & $20.00 \%$ \\
\hline 3 & $10.00 \%$ & $10.00 \%$ & $10.00 \%$ & $10.00 \%$ & $10.00 \%$ & $10.00 \%$ & $6.80 \%$ & $14.47 \%$ & $15.82 \%$ & $5.58 \%$ & $6.33 \%$ & $20.00 \%$ & $20.00 \%$ & $20.00 \%$ \\
\hline 4 & $10.00 \%$ & $10.00 \%$ & $10.00 \%$ & $9.92 \%$ & $10.00 \%$ & $10.00 \%$ & $7.04 \%$ & $14.97 \%$ & $16.54 \%$ & $5.72 \%$ & $6.56 \%$ & $20.00 \%$ & $20.00 \%$ & $20.00 \%$ \\
\hline 5 & $10.00 \%$ & $9.29 \%$ & $8.21 \%$ & $10.62 \%$ & $10.00 \%$ & $8.68 \%$ & $7.32 \%$ & $15.49 \%$ & $17.26 \%$ & $5.94 \%$ & $6.83 \%$ & $20.00 \%$ & $20.00 \%$ & $20.00 \%$ \\
\hline 6 & $10.50 \%$ & $6.24 \%$ & $8.35 \%$ & $10.94 \%$ & $10.00 \%$ & $5.69 \%$ & $7.49 \%$ & $16.00 \%$ & $17.98 \%$ & $6.05 \%$ & $7.07 \%$ & $20.00 \%$ & $20.00 \%$ & $20.00 \%$ \\
\hline 7 & $12.71 \%$ & $3.28 \%$ & $8.64 \%$ & $11.26 \%$ & $8.12 \%$ & $2.80 \%$ & $7.61 \%$ & $16.51 \%$ & $18.69 \%$ & $6.25 \%$ & $7.31 \%$ & $20.00 \%$ & $20.00 \%$ & $20.00 \%$ \\
\hline 8 & $14.91 \%$ & $3.08 \%$ & $8.96 \%$ & $11.69 \%$ & $8.17 \%$ & $2.73 \%$ & $7.78 \%$ & $17.03 \%$ & $19.41 \%$ & $6.39 \%$ & $7.56 \%$ & $20.00 \%$ & $20.00 \%$ & $20.00 \%$ \\
\hline 9 & $17.18 \%$ & $3.35 \%$ & $9.29 \%$ & $12.11 \%$ & $8.32 \%$ & $2.78 \%$ & $7.92 \%$ & $17.54 \%$ & $20.00 \%$ & $6.59 \%$ & $7.80 \%$ & $20.00 \%$ & $20.00 \%$ & $20.00 \%$ \\
\hline 10 & $18.13 \%$ & $3.62 \%$ & $9.62 \%$ & $12.49 \%$ & $8.62 \%$ & $2.81 \%$ & $8.15 \%$ & $18.01 \%$ & $20.00 \%$ & $6.75 \%$ & $8.05 \%$ & $20.00 \%$ & $20.00 \%$ & $20.00 \%$ \\
\hline 11 & $19.08 \%$ & $3.89 \%$ & $9.80 \%$ & $12.88 \%$ & $8.82 \%$ & $2.79 \%$ & $8.26 \%$ & $18.56 \%$ & $20.00 \%$ & $6.92 \%$ & $8.29 \%$ & $20.00 \%$ & $20.00 \%$ & $20.00 \%$ \\
\hline 12 & $20.00 \%$ & $4.16 \%$ & $10.02 \%$ & $13.27 \%$ & $9.07 \%$ & $2.80 \%$ & $8.45 \%$ & $19.09 \%$ & $20.00 \%$ & $7.04 \%$ & $8.53 \%$ & $20.00 \%$ & $20.00 \%$ & $20.00 \%$ \\
\hline 13 & $20.00 \%$ & $4.43 \%$ & $10.16 \%$ & $13.65 \%$ & $9.14 \%$ & $2.80 \%$ & $8.67 \%$ & $18.02 \%$ & $19.17 \%$ & $7.15 \%$ & $8.78 \%$ & $20.00 \%$ & $20.00 \%$ & $20.00 \%$ \\
\hline 14 & $20.00 \%$ & $4.70 \%$ & $10.31 \%$ & $14.72 \%$ & $9.16 \%$ & $2.81 \%$ & $8.89 \%$ & $14.11 \%$ & $14.62 \%$ & $7.27 \%$ & $9.02 \%$ & $20.00 \%$ & $15.73 \%$ & $20.00 \%$ \\
\hline 15 & $18.03 \%$ & $4.97 \%$ & $10.40 \%$ & $11.49 \%$ & $9.30 \%$ & $2.80 \%$ & $9.03 \%$ & $10.46 \%$ & $10.50 \%$ & $7.38 \%$ & $9.24 \%$ & $17.23 \%$ & $11.57 \%$ & $20.00 \%$ \\
\hline 16 & $12.86 \%$ & $5.25 \%$ & $9.62 \%$ & $8.72 \%$ & $9.09 \%$ & $2.71 \%$ & $8.18 \%$ & $7.03 \%$ & $6.68 \%$ & $7.42 \%$ & $8.59 \%$ & $12.91 \%$ & $7.65 \%$ & $15.84 \%$ \\
\hline 17 & $8.01 \%$ & $5.61 \%$ & $6.29 \%$ & $5.95 \%$ & $8.03 \%$ & $2.57 \%$ & $4.57 \%$ & $3.76 \%$ & $2.89 \%$ & $4.22 \%$ & $5.70 \%$ & $8.93 \%$ & $3.91 \%$ & $11.79 \%$ \\
\hline 18 & $3.40 \%$ & $1.89 \%$ & $3.14 \%$ & $2.45 \%$ & $4.17 \%$ & $2.39 \%$ & $1.58 \%$ & $0.67 \%$ & $0.00 \%$ & $1.18 \%$ & $2.98 \%$ & $5.21 \%$ & $0.00 \%$ & $7.81 \%$ \\
\hline 19 & $0.00 \%$ & $0.00 \%$ & $0.01 \%$ & $0.00 \%$ & $0.40 \%$ & $0.00 \%$ & $0.00 \%$ & $0.00 \%$ & $0.00 \%$ & $0.00 \%$ & $0.26 \%$ & $1.37 \%$ & $0.00 \%$ & $0.00 \%$ \\
\hline 20 & $0.00 \%$ & $0.00 \%$ & $0.00 \%$ & $0.00 \%$ & $0.00 \%$ & $0.00 \%$ & $0.00 \%$ & $0.00 \%$ & $0.00 \%$ & $0.00 \%$ & $0.00 \%$ & $0.00 \%$ & $0.00 \%$ & $0.00 \%$ \\
\hline
\end{tabular}




\begin{tabular}{|c|c|c|c|c|c|c|c|c|c|c|c|c|c|c|}
\hline \multicolumn{15}{|c|}{ Panel B: Level of Return Enhancement } \\
\hline 1 & 0.0569 & 0.0311 & 0.0389 & 0.0222 & 0.0000 & 0.0286 & 0.0245 & 0.0397 & 0.0539 & 0.0567 & 0.0462 & 0.0726 & 0.0896 & 0.1739 \\
\hline 2 & 0.0503 & 0.0197 & 0.0231 & 0.0180 & 0.0271 & 0.0205 & 0.0068 & 0.0205 & 0.0251 & 0.0255 & 0.0221 & 0.0530 & 0.0651 & 0.1492 \\
\hline 3 & 0.0455 & 0.0165 & 0.0202 & 0.0158 & 0.0250 & 0.0185 & 0.0049 & 0.0159 & 0.0204 & 0.0074 & 0.0074 & 0.0537 & 0.0592 & 0.1260 \\
\hline 4 & 0.0411 & 0.0141 & 0.0177 & 0.0138 & 0.0230 & 0.0167 & 0.0038 & 0.0162 & 0.0214 & 0.0038 & 0.0053 & 0.0552 & 0.0594 & 0.1054 \\
\hline 5 & 0.0372 & 0.0117 & 0.0132 & 0.0106 & 0.0211 & 0.0141 & 0.0031 & 0.0167 & 0.0225 & 0.0039 & 0.0055 & 0.0564 & 0.0596 & 0.0893 \\
\hline 6 & 0.0328 & 0.0085 & 0.0088 & 0.0077 & 0.0181 & 0.0099 & 0.0029 & 0.0172 & 0.0235 & 0.0039 & 0.0057 & 0.0575 & 0.0598 & 0.0822 \\
\hline 7 & 0.0259 & 0.0046 & 0.0049 & 0.0051 & 0.0132 & 0.0048 & 0.0030 & 0.0177 & 0.0246 & 0.0040 & 0.0059 & 0.0585 & 0.0599 & 0.0814 \\
\hline 8 & 0.0189 & 0.0005 & 0.0034 & 0.0051 & 0.0080 & 0.0003 & 0.0030 & 0.0182 & 0.0257 & 0.0041 & 0.0061 & 0.0595 & 0.0600 & 0.0811 \\
\hline 9 & 0.0146 & 0.0004 & 0.0036 & 0.0053 & 0.0029 & 0.0003 & 0.0031 & 0.0187 & 0.0268 & 0.0042 & 0.0063 & 0.0603 & 0.0602 & 0.0807 \\
\hline 10 & 0.0155 & 0.0005 & 0.0037 & 0.0056 & 0.0028 & 0.0003 & 0.0031 & 0.0192 & 0.0278 & 0.0042 & 0.0065 & 0.0611 & 0.0604 & 0.0798 \\
\hline 11 & 0.0163 & 0.0005 & 0.0038 & 0.0058 & 0.0029 & 0.0003 & 0.0031 & 0.0197 & 0.0287 & 0.0044 & 0.0067 & 0.0618 & 0.0608 & 0.0781 \\
\hline 12 & 0.0171 & 0.0006 & 0.0038 & 0.0060 & 0.0030 & 0.0003 & 0.0032 & 0.0202 & 0.0296 & 0.0044 & 0.0069 & 0.0628 & 0.0612 & 0.0760 \\
\hline 13 & 0.0180 & 0.0007 & 0.0038 & 0.0062 & 0.0030 & 0.0003 & 0.0032 & 0.0205 & 0.0299 & 0.0044 & 0.0071 & 0.0635 & 0.0596 & 0.0741 \\
\hline 14 & 0.0187 & 0.0007 & 0.0037 & 0.0065 & 0.0030 & 0.0003 & 0.0033 & 0.0190 & 0.0258 & 0.0043 & 0.0072 & 0.0602 & 0.0492 & 0.0712 \\
\hline 15 & 0.0184 & 0.0008 & 0.0037 & 0.0064 & 0.0030 & 0.0003 & 0.0033 & 0.0157 & 0.0191 & 0.0043 & 0.0074 & 0.0516 & 0.0373 & 0.0577 \\
\hline 16 & 0.0153 & 0.0009 & 0.0037 & 0.0054 & 0.0030 & 0.0002 & 0.0033 & 0.0109 & 0.0103 & 0.0043 & 0.0075 & 0.0406 & 0.0245 & 0.0414 \\
\hline 17 & 0.0107 & 0.0009 & 0.0032 & 0.0038 & 0.0025 & 0.0002 & 0.0025 & 0.0052 & 0.0016 & 0.0033 & 0.0062 & 0.0280 & 0.0109 & 0.0248 \\
\hline 18 & 0.0047 & 0.0006 & 0.0016 & 0.0017 & 0.0017 & 0.0002 & 0.0008 & 0.0001 & 0.0000 & 0.0008 & 0.0032 & 0.0142 & 0.0000 & 0.0080 \\
\hline 19 & 0.0000 & 0.0000 & 0.0000 & 0.0000 & 0.0002 & 0.0000 & 0.0000 & 0.0000 & 0.0000 & 0.0000 & 0.0000 & 0.0009 & 0.0000 & 0.0000 \\
\hline 20 & 0.0000 & 0.0000 & 0.0000 & 0.0000 & 0.0000 & 0.0000 & 0.0000 & 0.0000 & 0.0000 & 0.0000 & 0.0000 & 0.0000 & 0.0000 & 0.0000 \\
\hline
\end{tabular}


Exhibit 3A: Allocations and Level of Return Enhancement for Fifteen Year Time Horizons

\begin{tabular}{|c|c|c|c|c|c|c|c|c|c|}
\hline & 1994 & 1995 & 1996 & 1997 & 1998 & 1999 & 2000 & 2001 & 2002 \\
\hline \multicolumn{10}{|c|}{ Panel A: REIT Allocations } \\
\hline 1 & $11.92 \%$ & $12.98 \%$ & $13.85 \%$ & $13.54 \%$ & $10.00 \%$ & $7.88 \%$ & $13.44 \%$ & $19.67 \%$ & $0.00 \%$ \\
\hline 2 & $12.61 \%$ & $13.85 \%$ & $15.00 \%$ & $14.31 \%$ & $10.00 \%$ & $7.58 \%$ & $13.61 \%$ & $9.80 \%$ & $0.00 \%$ \\
\hline 3 & $13.77 \%$ & $14.37 \%$ & $16.25 \%$ & $15.44 \%$ & $10.00 \%$ & $7.12 \%$ & $14.10 \%$ & $20.00 \%$ & $20.00 \%$ \\
\hline 4 & $14.92 \%$ & $14.90 \%$ & $17.53 \%$ & $16.63 \%$ & $10.00 \%$ & $6.42 \%$ & $14.65 \%$ & $20.00 \%$ & $20.00 \%$ \\
\hline 5 & $16.03 \%$ & $15.54 \%$ & $18.84 \%$ & $17.75 \%$ & $9.99 \%$ & $5.66 \%$ & $15.20 \%$ & $20.00 \%$ & $20.00 \%$ \\
\hline 6 & $16.91 \%$ & $16.07 \%$ & $20.00 \%$ & $18.95 \%$ & $7.99 \%$ & $4.96 \%$ & $15.76 \%$ & $20.00 \%$ & $20.00 \%$ \\
\hline 7 & $17.44 \%$ & $16.64 \%$ & $20.00 \%$ & $20.00 \%$ & $8.23 \%$ & $3.83 \%$ & $16.31 \%$ & $20.00 \%$ & $20.00 \%$ \\
\hline 8 & $17.90 \%$ & $17.20 \%$ & $20.00 \%$ & $20.00 \%$ & $8.45 \%$ & $1.09 \%$ & $16.87 \%$ & $20.00 \%$ & $20.00 \%$ \\
\hline 9 & $18.36 \%$ & $17.69 \%$ & $20.00 \%$ & $20.00 \%$ & $8.71 \%$ & $0.09 \%$ & $17.41 \%$ & $20.00 \%$ & $20.00 \%$ \\
\hline 10 & $18.90 \%$ & $18.49 \%$ & $20.00 \%$ & $20.00 \%$ & $8.99 \%$ & $0.00 \%$ & $17.91 \%$ & $20.00 \%$ & $20.00 \%$ \\
\hline 11 & $19.42 \%$ & $19.07 \%$ & $20.00 \%$ & $20.00 \%$ & $9.26 \%$ & $0.00 \%$ & $18.56 \%$ & $20.00 \%$ & $20.00 \%$ \\
\hline 12 & $20.00 \%$ & $19.91 \%$ & $20.00 \%$ & $20.00 \%$ & $9.43 \%$ & $0.00 \%$ & $18.43 \%$ & $20.00 \%$ & $20.00 \%$ \\
\hline 13 & $20.00 \%$ & $19.10 \%$ & $20.00 \%$ & $20.00 \%$ & $9.73 \%$ & $0.00 \%$ & $15.44 \%$ & $20.00 \%$ & $20.00 \%$ \\
\hline 14 & $19.95 \%$ & $14.52 \%$ & $16.13 \%$ & $16.31 \%$ & $9.91 \%$ & $0.00 \%$ & $12.38 \%$ & $17.76 \%$ & $20.00 \%$ \\
\hline 15 & $15.35 \%$ & $10.90 \%$ & $12.15 \%$ & $12.57 \%$ & $10.09 \%$ & $0.00 \%$ & $9.69 \%$ & $13.90 \%$ & $18.64 \%$ \\
\hline 16 & $11.11 \%$ & $8.24 \%$ & $9.43 \%$ & $9.70 \%$ & $9.73 \%$ & $0.00 \%$ & $7.11 \%$ & $10.43 \%$ & $14.43 \%$ \\
\hline 17 & $7.09 \%$ & $4.77 \%$ & $6.80 \%$ & $6.90 \%$ & $6.94 \%$ & $0.00 \%$ & $4.61 \%$ & $7.05 \%$ & $10.41 \%$ \\
\hline 18 & $3.24 \%$ & $0.81 \%$ & $4.09 \%$ & $3.36 \%$ & $4.32 \%$ & $0.00 \%$ & $2.16 \%$ & $3.78 \%$ & $6.53 \%$ \\
\hline 19 & $0.00 \%$ & $0.00 \%$ & $0.01 \%$ & $0.00 \%$ & $1.25 \%$ & $0.00 \%$ & $0.00 \%$ & $0.06 \%$ & $2.78 \%$ \\
\hline 20 & $0.00 \%$ & $0.00 \%$ & $0.00 \%$ & $0.00 \%$ & $0.00 \%$ & $0.00 \%$ & $0.00 \%$ & $0.00 \%$ & $0.00 \%$ \\
\hline \multicolumn{10}{|c|}{ Panel B: Level of Return Enhancement } \\
\hline 1 & 0.0235 & 0.0115 & 0.0398 & 0.0454 & 0.0540 & 0.0420 & 0.0439 & 0.0517 & 0.1045 \\
\hline 2 & 0.0144 & 0.0095 & 0.0368 & 0.0357 & 0.0321 & 0.0209 & 0.0225 & 0.0287 & 0.0831 \\
\hline 3 & 0.0133 & 0.0092 & 0.0364 & 0.0349 & 0.0185 & 0.0095 & 0.0185 & 0.0201 & 0.0656 \\
\hline 4 & 0.0127 & 0.0094 & 0.0366 & 0.0344 & 0.0151 & 0.0070 & 0.0181 & 0.0209 & 0.0527 \\
\hline 5 & 0.0125 & 0.0097 & 0.0372 & 0.0344 & 0.0125 & 0.0053 & 0.0183 & 0.0215 & 0.0452 \\
\hline 6 & 0.0126 & 0.0101 & 0.0381 & 0.0347 & 0.0102 & 0.0038 & 0.0190 & 0.0221 & 0.0459 \\
\hline 7 & 0.0130 & 0.0105 & 0.0399 & 0.0353 & 0.0079 & 0.0026 & 0.0196 & 0.0227 & 0.0465 \\
\hline 8 & 0.0134 & 0.0108 & 0.0412 & 0.0370 & 0.0059 & 0.0009 & 0.0203 & 0.0232 & 0.0470 \\
\hline 9 & 0.0139 & 0.0112 & 0.0421 & 0.0379 & 0.0049 & 0.0000 & 0.0210 & 0.0236 & 0.0476 \\
\hline 10 & 0.0145 & 0.0116 & 0.0429 & 0.0387 & 0.0050 & 0.0000 & 0.0217 & 0.0241 & 0.0481 \\
\hline 11 & 0.0151 & 0.0122 & 0.0437 & 0.0396 & 0.0052 & 0.0000 & 0.0223 & 0.0245 & 0.0484 \\
\hline 12 & 0.0158 & 0.0128 & 0.0445 & 0.0403 & 0.0053 & 0.0000 & 0.0228 & 0.0249 & 0.0483 \\
\hline 13 & 0.0164 & 0.0133 & 0.0431 & 0.0410 & 0.0053 & 0.0000 & 0.0222 & 0.0251 & 0.0481 \\
\hline 14 & 0.0170 & 0.0125 & 0.0373 & 0.0364 & 0.0053 & 0.0000 & 0.0200 & 0.0230 & 0.0479 \\
\hline 15 & 0.0157 & 0.0104 & 0.0297 & 0.0296 & 0.0053 & 0.0000 & 0.0166 & 0.0193 & 0.0439 \\
\hline 16 & 0.0126 & 0.0076 & 0.0210 & 0.0216 & 0.0053 & 0.0000 & 0.0121 & 0.0148 & 0.0355 \\
\hline 17 & 0.0085 & 0.0043 & 0.0115 & 0.0132 & 0.0047 & 0.0000 & 0.0069 & 0.0095 & 0.0265 \\
\hline 18 & 0.0032 & 0.0005 & 0.0020 & 0.0041 & 0.0032 & 0.0000 & 0.0015 & 0.0036 & 0.0169 \\
\hline 19 & 0.0000 & 0.0000 & 0.0000 & 0.0000 & 0.0009 & 0.0000 & 0.0000 & 0.0000 & 0.0068 \\
\hline 20 & 0.0000 & 0.0000 & 0.0000 & 0.0000 & 0.0000 & 0.0000 & 0.0000 & 0.0000 & 0.0000 \\
\hline
\end{tabular}


Exhibit 4A: Allocations and Level of Return Enhancement for Twenty Year Time Horizons

\begin{tabular}{|c|c|c|c|c|}
\hline & 1999 & 2000 & 2001 & 2002 \\
\hline \multicolumn{5}{|l|}{ Panel A: REIT Allocations } \\
\hline 1 & $8.70 \%$ & $16.29 \%$ & $20.00 \%$ & $20.00 \%$ \\
\hline 2 & $8.87 \%$ & $17.46 \%$ & $20.00 \%$ & $20.00 \%$ \\
\hline 3 & $9.15 \%$ & $18.85 \%$ & $20.00 \%$ & $20.00 \%$ \\
\hline 4 & $9.45 \%$ & $20.00 \%$ & $20.00 \%$ & $20.00 \%$ \\
\hline 5 & $9.76 \%$ & $20.00 \%$ & $20.00 \%$ & $20.00 \%$ \\
\hline 6 & $10.07 \%$ & $20.00 \%$ & $20.00 \%$ & $20.00 \%$ \\
\hline 7 & $10.38 \%$ & $20.00 \%$ & $20.00 \%$ & $20.00 \%$ \\
\hline 8 & $10.68 \%$ & $20.00 \%$ & $20.00 \%$ & $20.00 \%$ \\
\hline 9 & $11.00 \%$ & $20.00 \%$ & $20.00 \%$ & $20.00 \%$ \\
\hline 10 & $11.31 \%$ & $20.00 \%$ & $20.00 \%$ & $20.00 \%$ \\
\hline 11 & $11.62 \%$ & $20.00 \%$ & $20.00 \%$ & $20.00 \%$ \\
\hline 12 & $11.92 \%$ & $19.30 \%$ & $20.00 \%$ & $20.00 \%$ \\
\hline 13 & $12.24 \%$ & $15.47 \%$ & $20.00 \%$ & $20.00 \%$ \\
\hline 14 & $12.54 \%$ & $12.77 \%$ & $17.58 \%$ & $19.03 \%$ \\
\hline 15 & $10.03 \%$ & $9.85 \%$ & $14.27 \%$ & $15.24 \%$ \\
\hline 16 & $6.25 \%$ & $6.10 \%$ & $10.39 \%$ & $11.59 \%$ \\
\hline 17 & $2.75 \%$ & $2.31 \%$ & $6.70 \%$ & $8.05 \%$ \\
\hline 18 & $0.00 \%$ & $0.00 \%$ & $2.60 \%$ & $4.59 \%$ \\
\hline 19 & $0.00 \%$ & $0.00 \%$ & $0.00 \%$ & $0.99 \%$ \\
\hline 20 & $0.00 \%$ & $0.00 \%$ & $0.00 \%$ & $0.00 \%$ \\
\hline \multicolumn{5}{|l|}{ Panel B: Level of Return Enhancement } \\
\hline 1 & 0.0227 & 0.0298 & 0.0492 & 0.0663 \\
\hline 2 & 0.0104 & 0.0256 & 0.0400 & 0.0544 \\
\hline 3 & 0.0089 & 0.0262 & 0.0409 & 0.0499 \\
\hline 4 & 0.0083 & 0.0272 & 0.0413 & 0.0495 \\
\hline 5 & 0.0083 & 0.0283 & 0.0416 & 0.0495 \\
\hline 6 & 0.0085 & 0.0293 & 0.0418 & 0.0496 \\
\hline 7 & 0.0088 & 0.0302 & 0.0421 & 0.0496 \\
\hline 8 & 0.0090 & 0.0310 & 0.0425 & 0.0497 \\
\hline 9 & 0.0092 & 0.0318 & 0.0429 & 0.0499 \\
\hline 10 & 0.0095 & 0.0325 & 0.0434 & 0.0501 \\
\hline 11 & 0.0097 & 0.0332 & 0.0439 & 0.0502 \\
\hline 12 & 0.0100 & 0.0329 & 0.0441 & 0.0504 \\
\hline 13 & 0.0103 & 0.0286 & 0.0396 & 0.0504 \\
\hline 14 & 0.0106 & 0.0227 & 0.0329 & 0.0446 \\
\hline 15 & 0.0104 & 0.0162 & 0.0257 & 0.0366 \\
\hline 16 & 0.0082 & 0.0088 & 0.0176 & 0.0281 \\
\hline 17 & 0.0042 & 0.0016 & 0.0089 & 0.0192 \\
\hline 18 & 0.0000 & 0.0000 & 0.0018 & 0.0099 \\
\hline 19 & 0.0000 & 0.0000 & 0.0000 & 0.0012 \\
\hline 20 & 0.0000 & 0.0000 & 0.0000 & 0.0000 \\
\hline
\end{tabular}


Exhibit 5A: Allocations and Level of Risk Reduction for Five Year Time Horizons

\begin{tabular}{|c|c|c|c|c|c|c|c|c|c|c|c|c|c|c|c|c|c|c|c|}
\hline & 1984 & 1985 & 1986 & 1987 & 1988 & 1989 & 1990 & 1991 & 1992 & 1993 & 1994 & 1995 & 1996 & 1997 & 1998 & 1999 & 2000 & 2001 & 2002 \\
\hline \multicolumn{20}{|c|}{ anel A: REIT Allocations } \\
\hline 1 & $4.90 \%$ & $5.81 \%$ & $10.00 \%$ & $10.00 \%$ & $10.00 \%$ & $10.00 \%$ & $09 \%$ & $09 \%$ & $11.51 \%$ & $39 \%$ & $16.61 \%$ & $13.40 \%$ & $13.69 \%$ & $14.92 \%$ & $10.96 \%$ & $.60 \%$ & $17.66 \%$ & $2 \%$ & $.58 \%$ \\
\hline 2 & $7.98 \%$ & $.36 \%$ & $.00 \%$ & $10.00 \%$ & $10.00 \%$ & $00 \%$ & $4 \%$ & $84 \%$ & $\%$ & $8 \%$ & $\%$ & $10.24 \%$ & $12.29 \%$ & $38 \%$ & $2 \%$ & $30 \%$ & $5 \%$ & & $48 \%$ \\
\hline 3 & $10.89 \%$ & $6.90 \%$ & $10.31 \%$ & $10.00 \%$ & $10.00 \%$ & $10.00 \%$ & $97 \%$ & $.00 \%$ & $4 \%$ & $4 \%$ & $17.04 \%$ & $01 \%$ & $12.89 \%$ & $15.32 \%$ & $.80 \%$ & $32 \%$ & $5 \%$ & $4 \%$ & $53 \%$ \\
\hline 4 & $15.16 \%$ & $7.45 \% 1$ & & $.00 \%$ & $0 \%$ & & & & & $9 \%$ & $7 \%$ & & $13.50 \%$ & $3.26 \%$ & $.8 \%$ & & $\%$ & $6 \%$ & $53 \%$ \\
\hline 5 & $17.03 \%$ & $7.97 \% 1$ & $8 \%$ & $10.00 \%$ & $.00 \%$ & & $\%$ & & & $3 \%$ & & & $1 \%$ & $\%$ & $5 \%$ & & & $3 \%$ & $54 \%$ \\
\hline 6 & $18.89 \%$ & $8.49 \% 1$ & $14.77 \%$ & $10.00 \%$ & $.00 \%$ & $\%$ & $00 \%$ & $00 \%$ & $00 \%$ & $0 \% \%$ & $\%$ & & $14.71 \%$ & $18.14 \%$ & $9.93 \%$ & $\%$ & $\%$ & $0 \%$ & $58 \%$ \\
\hline 7 & $20.00 \%$ & $9.01 \% 1$ & $16.25 \%$ & $10.00 \%$ & $10.00 \%$ & $54 \%$ & $.00 \%$ & $.00 \%$ & $0.00 \%$ & $0.00 \%$ & $55 \%$ & $8.69 \%$ & $15.32 \%$ & $19.09 \%$ & $10.31 \%$ & $1.69 \%$ & $00 \%$ & $11.01 \%$ & $3.70 \%$ \\
\hline 8 & $20.00 \%$ & $9.52 \% 1$ & $17.74 \%$ & $10.00 \%$ & $.00 \%$ & $72 \%$ & $.00 \%$ & $.00 \%$ & $0.00 \%$ & $.00 \%$ & $0 \%$ & & $92 \%$ & $7 \%$ & $10.69 \%$ & $9 \%$ & $0 \%$ & $3 \%$ & $3.77 \%$ \\
\hline 9 & $20.00 \% 1$ & $10.04 \% 1$ & $19.23 \%$ & $10.00 \%$ & $10.00 \%$ & $3.90 \%$ & $0.00 \%$ & $0.00 \%$ & $0.00 \%$ & $00 \%$ & $20.00 \%$ & $\%$ & $16.53 \%$ & $0 \%$ & $11.06 \%$ & $3 \%$ & $\%$ & $5 \%$ & $.93 \%$ \\
\hline 10 & $20.00 \%$ & $10.56 \% 2$ & $\%$ & $50 \%$ & $38 \%$ & $3 \%$ & $\%$ & $0 \%$ & $0 \%$ & $0 \%$ & $0 \%$ & $\%$ & $3 \%$ & $0 \%$ & $44 \%$ & $\%$ & $\%$ & $1 \%$ & $07 \%$ \\
\hline 11 & 20. & $11.07 \% 2$ & & & $\%$ & & & & $\%$ & $\%$ & & & $4 \%$ & $\%$ & $2 \%$ & & & $\%$ & $3 \%$ \\
\hline 12 & 20. & & & & $\%$ & & & & & & & & $5 \%$ & $\%$ & & & & D\% & $6 \%$ \\
\hline 13 & $20.00 \%$ & 12.1 & & $\%$ & $20.00 \%$ & $\%$ & $\%$ & $\%$ & $0 \%$ & $\%$ & $0 \%$ & $1 \%$ & $6 \%$ & $0 \%$ & $7 \%$ & $3 \%$ & $\%$ & $7.54 \%$ & $.36 \%$ \\
\hline 14 & $20.00 \%$ & $12.62 \%$ & $20.00 \%$ & $20.00 \%$ & $20.00 \%$ & $0.00 \%$ & $0.00 \%$ & $0.00 \%$ & $0.00 \%$ & $.00 \%$ & $20.00 \%$ & $10.37 \%$ & $19.59 \%$ & $20.00 \%$ & $12.95 \%$ & $2.23 \%$ & $0 \%$ & $6.69 \%$ & $7.62 \%$ \\
\hline 15 & $20.00 \%$ & $11.64 \% 2$ & $20.00 \%$ & $20.00 \%$ & $20.00 \%$ & $0.00 \%$ & $0.00 \%$ & $.00 \%$ & $0.00 \%$ & $00 \%$ & $20.00 \%$ & $11.02 \%$ & $20.00 \%$ & $20.00 \%$ & $13.32 \%$ & $2.29 \%$ & $8 \%$ & $5.83 \%$ & $.89 \%$ \\
\hline 16 & $20.00 \%$ & $7.32 \% 2$ & $20.00 \%$ & $20.00 \%$ & $20.00 \%$ & $\%$ & $.00 \%$ & $.00 \%$ & $0.00 \%$ & $\%$ & $4 \%$ & $\%$ & $20.00 \%$ & $20.00 \%$ & $10.69 \%$ & $2.35 \%$ & & $2.49 \%$ & $15 \%$ \\
\hline 17 & $20.00 \%$ & $2.80 \% 2$ & $20.00 \%$ & $16.18 \%$ & $16.55 \%$ & & $\%$ & & $0.00 \%$ & & $3 \%$ & & $18.68 \%$ & $13.56 \%$ & $7.58 \%$ & $2.40 \%$ & & $0.00 \%$ & $5.41 \%$ \\
\hline 18 & $20.00 \%$ & $0.00 \% 1$ & $16.47 \%$ & $10.07 \%$ & $11.04 \%$ & & & & $\%$ & & & & $15.28 \%$ & $9.82 \%$ & $4.55 \%$ & & & $0 \%$ & $.65 \%$ \\
\hline 19 & $20.00 \%$ & $0.00 \%$ & $9.02 \%$ & $3.72 \%$ & $5.52 \%$ & $0.00 \%$ & $0.00 \%$ & $.00 \%$ & $0.00 \%$ & $.00 \%$ & $0.00 \%$ & $3.04 \%$ & $7.78 \%$ & $0.00 \%$ & $1.53 \%$ & $0.00 \%$ & $2.99 \%$ & $0.00 \%$ & $3.46 \%$ \\
\hline 20 & $0.00 \%$ & $0.00 \%$ & $0.00 \%$ & $0.00 \%$ & $0.00 \%$ & $0.00 \%$ & $0.00 \%$ & $0.00 \%$ & $0.00 \%$ & $0.00 \%$ & $0.00 \%$ & $0.00 \%$ & $0.00 \%$ & $0.00 \%$ & $0.00 \%$ & $0.00 \%$ & $0.00 \%$ & $0.00 \%$ & $0.00 \%$ \\
\hline
\end{tabular}




\section{Panel B: Level of Risk Reduction}

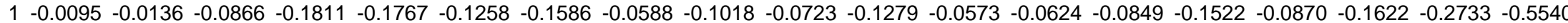

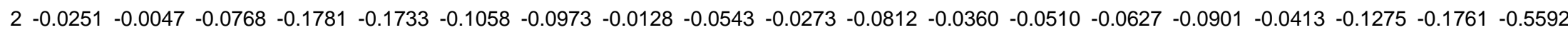

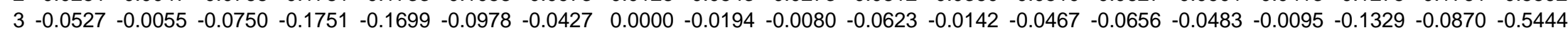

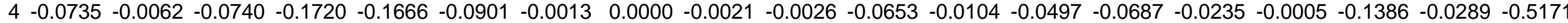

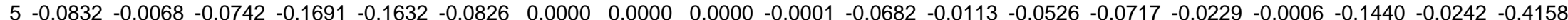

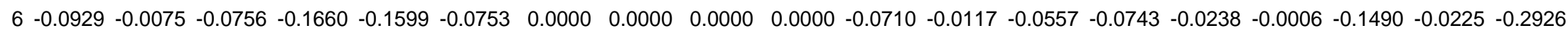

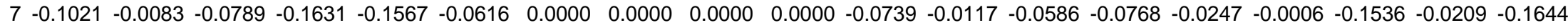

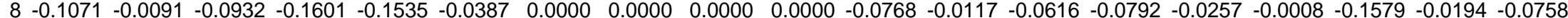

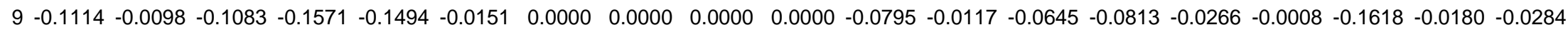

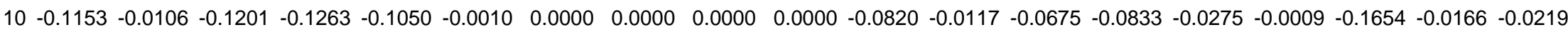

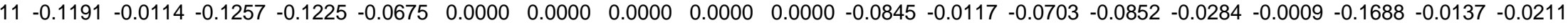

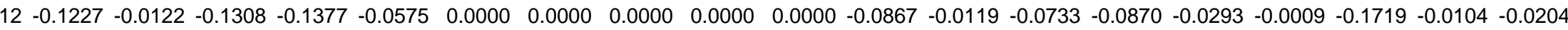

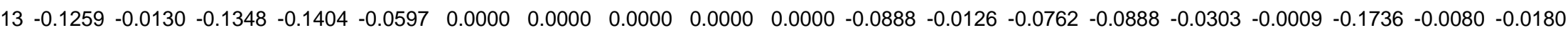

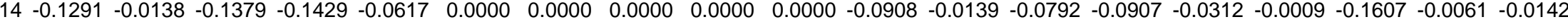

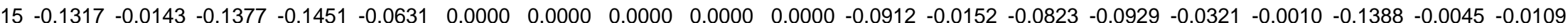

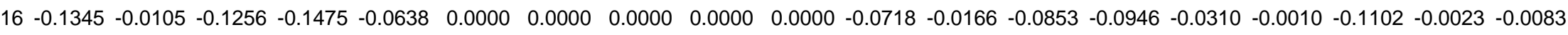

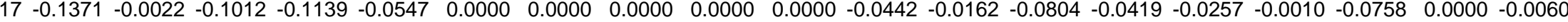

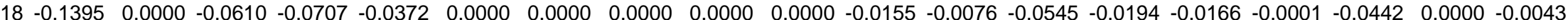

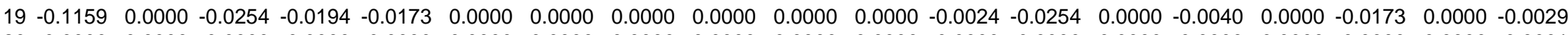
\begin{tabular}{lllllllllllllllllllll}
20 & 0.0000 & 0.0000 & 0.0000 & 0.0000 & 0.0000 & 0.0000 & 0.0000 & 0.0000 & 0.0000 & 0.0000 & 0.0000 & 0.0000 & 0.0000 & 0.0000 & 0.0000 & 0.0000 & 0.0000 & 0.0000 & -0.0001 \\
\hline
\end{tabular} 
Exhibit 6A: Allocations and Level of Risk Reduction for Ten Year Time Horizons

\begin{tabular}{|c|c|c|c|c|c|c|c|c|c|c|c|c|c|c|}
\hline & 1989 & 1990 & 1991 & 1992 & 1993 & 1994 & 1995 & 1996 & 1997 & 1998 & 1999 & 2000 & 2001 & 2002 \\
\hline \multicolumn{15}{|c|}{ Panel A: REIT Allocations } \\
\hline 1 & $10.00 \%$ & $10.00 \%$ & $10.00 \%$ & $10.00 \%$ & $10.00 \%$ & $10.00 \%$ & $8.72 \%$ & $12.30 \%$ & $14.16 \%$ & $9.06 \%$ & $8.61 \%$ & $19.49 \%$ & $20.00 \%$ & $0.00 \%$ \\
\hline 2 & $10.00 \%$ & $10.00 \%$ & $10.00 \%$ & $10.00 \%$ & $10.00 \%$ & $10.00 \%$ & $7.84 \%$ & $13.67 \%$ & $14.76 \%$ & $5.76 \%$ & $6.03 \%$ & $20.00 \%$ & $20.00 \%$ & $0.00 \%$ \\
\hline 3 & $10.00 \%$ & $10.00 \%$ & $10.00 \%$ & $10.00 \%$ & $10.00 \%$ & $10.00 \%$ & $6.97 \%$ & $14.17 \%$ & $15.38 \%$ & $5.54 \%$ & $6.28 \%$ & $20.00 \%$ & $20.00 \%$ & $0.00 \%$ \\
\hline 4 & $10.00 \%$ & $10.00 \%$ & $10.00 \%$ & $10.00 \%$ & $10.00 \%$ & $10.00 \%$ & $7.02 \%$ & $14.68 \%$ & $16.07 \%$ & $5.72 \%$ & $6.52 \%$ & $20.00 \%$ & $20.00 \%$ & $0.00 \%$ \\
\hline 5 & $10.00 \%$ & $10.00 \%$ & $9.31 \%$ & $10.49 \%$ & $10.00 \%$ & $10.00 \%$ & $7.25 \%$ & $15.18 \%$ & $16.77 \%$ & $5.88 \%$ & $6.76 \%$ & $20.00 \%$ & $20.00 \%$ & $0.00 \%$ \\
\hline 6 & $10.00 \%$ & $7.45 \%$ & $8.26 \%$ & $10.88 \%$ & $10.00 \%$ & $7.04 \%$ & $7.43 \%$ & $15.69 \%$ & $17.46 \%$ & $6.05 \%$ & $7.01 \%$ & $20.00 \%$ & $20.00 \%$ & $0.00 \%$ \\
\hline 7 & $10.10 \%$ & $3.94 \%$ & $8.59 \%$ & $11.26 \%$ & $8.91 \%$ & $3.47 \%$ & $7.60 \%$ & $16.19 \%$ & $18.15 \%$ & $6.22 \%$ & $7.25 \%$ & $20.00 \%$ & $20.00 \%$ & $0.00 \%$ \\
\hline 8 & $13.01 \%$ & $3.07 \%$ & $8.92 \%$ & $11.64 \%$ & $8.20 \%$ & $2.73 \%$ & $7.76 \%$ & $16.69 \%$ & $18.85 \%$ & $6.38 \%$ & $7.49 \%$ & $20.00 \%$ & $20.00 \%$ & $0.00 \%$ \\
\hline 9 & $15.92 \%$ & $3.34 \%$ & $9.25 \%$ & $12.03 \%$ & $8.31 \%$ & $2.77 \%$ & $7.93 \%$ & $17.20 \%$ & $19.54 \%$ & $6.55 \%$ & $7.73 \%$ & $20.00 \%$ & $20.00 \%$ & $0.00 \%$ \\
\hline 10 & $17.64 \%$ & $3.61 \%$ & $9.59 \%$ & $12.41 \%$ & $8.55 \%$ & $2.78 \%$ & $8.10 \%$ & $17.70 \%$ & $20.00 \%$ & $6.72 \%$ & $7.98 \%$ & $20.00 \%$ & $20.00 \%$ & $0.00 \%$ \\
\hline 11 & $18.56 \%$ & $3.88 \%$ & $9.81 \%$ & $12.79 \%$ & $8.84 \%$ & $2.79 \%$ & $8.26 \%$ & $18.20 \%$ & $20.00 \%$ & $6.88 \%$ & $8.22 \%$ & $20.00 \%$ & $20.00 \%$ & $0.00 \%$ \\
\hline 12 & $19.49 \%$ & $4.15 \%$ & $9.95 \%$ & $13.18 \%$ & $9.14 \%$ & $2.79 \%$ & $8.45 \%$ & $18.71 \%$ & $20.00 \%$ & $7.03 \%$ & $8.46 \%$ & $20.00 \%$ & $20.00 \%$ & $0.00 \%$ \\
\hline 13 & $20.00 \%$ & $4.42 \%$ & $10.09 \%$ & $13.56 \%$ & $9.13 \%$ & $2.80 \%$ & $8.64 \%$ & $19.21 \%$ & $20.00 \%$ & $7.14 \%$ & $8.71 \%$ & $20.00 \%$ & $20.00 \%$ & $0.00 \%$ \\
\hline 14 & $20.00 \%$ & $4.70 \%$ & $10.24 \%$ & $13.95 \%$ & $9.18 \%$ & $2.81 \%$ & $8.79 \%$ & $16.98 \%$ & $18.86 \%$ & $7.26 \%$ & $8.95 \%$ & $20.00 \%$ & $20.00 \%$ & $0.00 \%$ \\
\hline 15 & $20.00 \%$ & $4.97 \%$ & $10.41 \%$ & $12.20 \%$ & $9.34 \%$ & $2.81 \%$ & $8.94 \%$ & $12.83 \%$ & $13.63 \%$ & $7.37 \%$ & $9.19 \%$ & $20.00 \%$ & $20.00 \%$ & $0.00 \%$ \\
\hline 16 & $15.93 \%$ & $5.24 \%$ & $9.99 \%$ & $9.32 \%$ & $9.10 \%$ & $2.71 \%$ & $8.66 \%$ & $8.68 \%$ & $8.40 \%$ & $7.49 \%$ & $9.24 \%$ & $20.00 \%$ & $14.39 \%$ & $0.00 \%$ \\
\hline 17 & $10.14 \%$ & $5.60 \%$ & $6.73 \%$ & $6.43 \%$ & $8.41 \%$ & $2.55 \%$ & $4.93 \%$ & $4.54 \%$ & $3.17 \%$ & $4.53 \%$ & $6.26 \%$ & $14.92 \%$ & $6.95 \%$ & $0.00 \%$ \\
\hline 18 & $4.35 \%$ & $1.98 \%$ & $3.31 \%$ & $2.71 \%$ & $4.42 \%$ & $2.39 \%$ & $1.70 \%$ & $0.69 \%$ & $0.00 \%$ & $1.22 \%$ & $3.27 \%$ & $8.24 \%$ & $0.00 \%$ & $0.00 \%$ \\
\hline 19 & $0.00 \%$ & $0.00 \%$ & $0.28 \%$ & $0.00 \%$ & $0.43 \%$ & $0.00 \%$ & $0.00 \%$ & $0.00 \%$ & $0.00 \%$ & $0.00 \%$ & $0.28 \%$ & $1.56 \%$ & $0.00 \%$ & $0.00 \%$ \\
\hline 20 & $0.00 \%$ & $0.00 \%$ & $0.00 \%$ & $0.00 \%$ & $0.00 \%$ & $0.00 \%$ & $0.00 \%$ & $0.00 \%$ & $0.00 \%$ & $0.00 \%$ & $0.00 \%$ & $0.00 \%$ & $0.00 \%$ & $0.00 \%$ \\
\hline
\end{tabular}




\begin{tabular}{|c|c|c|c|c|c|c|c|c|c|c|c|c|c|c|}
\hline \multicolumn{15}{|c|}{ Panel B: Level of Risk Reduction } \\
\hline 1 & -0.0816 & -0.0735 & -0.0850 & -0.0519 & -0.0833 & -0.0617 & -0.0646 & -0.1025 & -0.0953 & -0.1109 & -0.0948 & -0.1423 & -0.2237 & -0.3607 \\
\hline 2 & -0.0755 & -0.0474 & -0.0515 & -0.0429 & -0.0614 & -0.0452 & -0.0182 & -0.0535 & -0.0448 & -0.0520 & -0.0467 & -0.1046 & -0.1645 & -0.3831 \\
\hline 3 & -0.0711 & -0.0407 & -0.0462 & -0.0386 & -0.0574 & -0.0415 & -0.0134 & -0.0416 & -0.0366 & -0.0152 & -0.0156 & -0.1071 & -0.1510 & -0.3803 \\
\hline 4 & -0.0669 & -0.0356 & -0.0412 & -0.0343 & -0.0536 & -0.0380 & -0.0102 & -0.0423 & -0.0386 & -0.0078 & -0.0113 & -0.1107 & -0.1531 & -0.3493 \\
\hline 5 & -0.0627 & -0.0307 & -0.0344 & -0.0284 & -0.0499 & -0.0346 & -0.0086 & -0.0438 & -0.0406 & -0.0080 & -0.0117 & -0.1139 & -0.1549 & -0.3052 \\
\hline 6 & -0.0586 & -0.0240 & -0.0233 & -0.0207 & -0.0462 & -0.0264 & -0.0080 & -0.0451 & -0.0426 & -0.0081 & -0.0121 & -0.1168 & -0.1566 & -0.2881 \\
\hline 7 & -0.0544 & -0.0136 & -0.0131 & -0.0139 & -0.0371 & -0.0137 & -0.0081 & -0.0466 & -0.0447 & -0.0083 & -0.0126 & -0.1193 & -0.1581 & -0.2905 \\
\hline 8 & -0.0413 & -0.0014 & -0.0091 & -0.0138 & -0.0229 & -0.0009 & -0.0083 & -0.0480 & -0.0467 & -0.0084 & -0.0130 & -0.1216 & -0.1597 & -0.2943 \\
\hline 9 & -0.0332 & -0.0013 & -0.0095 & -0.0145 & -0.0085 & -0.0010 & -0.0084 & -0.0494 & -0.0488 & -0.0086 & -0.0134 & -0.1236 & -0.1617 & -0.2985 \\
\hline 10 & -0.0359 & -0.0015 & -0.0099 & -0.0153 & -0.0083 & -0.0010 & -0.0085 & -0.0508 & -0.0508 & -0.0087 & -0.0139 & -0.1255 & -0.1639 & -0.3032 \\
\hline 11 & -0.0384 & -0.0017 & -0.0102 & -0.0160 & -0.0086 & -0.0009 & -0.0086 & -0.0522 & -0.0527 & -0.0090 & -0.0143 & -0.1273 & -0.1658 & -0.3079 \\
\hline 12 & -0.0410 & -0.0018 & -0.0102 & -0.0167 & -0.0090 & -0.0009 & -0.0088 & -0.0536 & -0.0545 & -0.0090 & -0.0147 & -0.1292 & -0.1677 & -0.3124 \\
\hline 13 & -0.0435 & -0.0020 & -0.0102 & -0.0174 & -0.0092 & -0.0009 & -0.0089 & -0.0550 & -0.0563 & -0.0090 & -0.0152 & -0.1313 & -0.1695 & -0.3182 \\
\hline 14 & -0.0459 & -0.0023 & -0.0103 & -0.0181 & -0.0090 & -0.0009 & -0.0091 & -0.0552 & -0.0564 & -0.0091 & -0.0156 & -0.1336 & -0.1715 & -0.3232 \\
\hline 15 & -0.0480 & -0.0024 & -0.0103 & -0.0182 & -0.0091 & -0.0008 & -0.0092 & -0.0490 & -0.0465 & -0.0091 & -0.0160 & -0.1358 & -0.1713 & -0.3273 \\
\hline 16 & -0.0447 & -0.0027 & -0.0104 & -0.0160 & -0.0091 & -0.0008 & -0.0093 & -0.0365 & -0.0277 & -0.0092 & -0.0163 & -0.1277 & -0.1289 & -0.3307 \\
\hline 17 & -0.0335 & -0.0030 & -0.0092 & -0.0117 & -0.0081 & -0.0008 & -0.0073 & -0.0182 & -0.0045 & -0.0075 & -0.0143 & -0.0990 & -0.0623 & -0.3161 \\
\hline 18 & -0.0159 & -0.0018 & -0.0050 & -0.0053 & -0.0055 & -0.0007 & -0.0024 & -0.0003 & 0.0000 & -0.0018 & -0.0079 & -0.0551 & 0.0000 & -0.1194 \\
\hline 19 & 0.0000 & 0.0000 & 0.0000 & 0.0000 & -0.0006 & 0.0000 & 0.0000 & 0.0000 & 0.0000 & 0.0000 & -0.0001 & -0.0038 & 0.0000 & 0.0000 \\
\hline 20 & 0.0000 & 0.0000 & 0.0000 & 0.0000 & 0.0000 & 0.0000 & 0.0000 & 0.0000 & 0.0000 & 0.0000 & 0.0000 & 0.0000 & 0.0000 & 0.0000 \\
\hline
\end{tabular}


Exhibit 7A: Allocations and Level of Risk Reduction for Fifteen Year Time Horizons

\begin{tabular}{|c|c|c|c|c|c|c|c|c|c|}
\hline & 1994 & 1995 & 1996 & 1997 & 1998 & 1999 & 2000 & 2001 & 2002 \\
\hline \multicolumn{10}{|c|}{ Panel A: REIT Allocations } \\
\hline 1 & $10.78 \%$ & $12.29 \%$ & $11.96 \%$ & $11.64 \%$ & $10.00 \%$ & $8.84 \%$ & $11.66 \%$ & $18.05 \%$ & $20.00 \%$ \\
\hline 2 & $11.95 \%$ & $13.63 \%$ & $13.24 \%$ & $12.82 \%$ & $10.00 \%$ & $8.08 \%$ & $12.88 \%$ & $18.89 \%$ & $20.00 \%$ \\
\hline 3 & $13.12 \%$ & $14.18 \%$ & $14.51 \%$ & $13.99 \%$ & $10.00 \%$ & $7.31 \%$ & $13.73 \%$ & $19.72 \%$ & $20.00 \%$ \\
\hline 4 & $14.29 \%$ & $14.74 \%$ & $15.79 \%$ & $15.16 \%$ & $10.00 \%$ & $6.55 \%$ & $14.27 \%$ & $20.00 \%$ & $20.00 \%$ \\
\hline 5 & $15.45 \%$ & $15.29 \%$ & $17.06 \%$ & $16.33 \%$ & $9.80 \%$ & $5.79 \%$ & $14.82 \%$ & $20.00 \%$ & $20.00 \%$ \\
\hline 6 & $16.61 \%$ & $15.85 \%$ & $18.33 \%$ & $17.51 \%$ & $8.48 \%$ & $5.02 \%$ & $15.37 \%$ & $20.00 \%$ & $20.00 \%$ \\
\hline 7 & $17.10 \%$ & $16.40 \%$ & $19.61 \%$ & $18.68 \%$ & $8.14 \%$ & $4.06 \%$ & $15.91 \%$ & $20.00 \%$ & $20.00 \%$ \\
\hline 8 & $17.60 \%$ & $16.95 \%$ & $20.00 \%$ & $19.85 \%$ & $8.41 \%$ & $1.16 \%$ & $16.46 \%$ & $20.00 \%$ & $20.00 \%$ \\
\hline 9 & $18.10 \%$ & $17.51 \%$ & $20.00 \%$ & $20.00 \%$ & $8.69 \%$ & $0.11 \%$ & $17.00 \%$ & $20.00 \%$ & $20.00 \%$ \\
\hline 10 & $18.60 \%$ & $18.12 \%$ & $20.00 \%$ & $20.00 \%$ & $8.97 \%$ & $0.11 \%$ & $17.55 \%$ & $20.00 \%$ & $20.00 \%$ \\
\hline 11 & $19.09 \%$ & $18.75 \%$ & $20.00 \%$ & $20.00 \%$ & $9.25 \%$ & $0.11 \%$ & $18.10 \%$ & $20.00 \%$ & $20.00 \%$ \\
\hline 12 & $19.59 \%$ & $19.43 \%$ & $20.00 \%$ & $20.00 \%$ & $9.47 \%$ & $0.11 \%$ & $18.64 \%$ & $20.00 \%$ & $20.00 \%$ \\
\hline 13 & $20.00 \%$ & $20.00 \%$ & $20.00 \%$ & $20.00 \%$ & $9.65 \%$ & $0.11 \%$ & $17.75 \%$ & $20.00 \%$ & $20.00 \%$ \\
\hline 14 & $20.00 \%$ & $17.00 \%$ & $20.00 \%$ & $20.00 \%$ & $9.82 \%$ & $0.11 \%$ & $14.70 \%$ & $20.00 \%$ & $20.00 \%$ \\
\hline 15 & $18.50 \%$ & $12.29 \%$ & $18.40 \%$ & $17.77 \%$ & $10.00 \%$ & $0.10 \%$ & $11.41 \%$ & $17.19 \%$ & $20.00 \%$ \\
\hline 16 & $13.63 \%$ & $9.21 \%$ & $12.83 \%$ & $12.83 \%$ & $10.20 \%$ & $0.09 \%$ & $8.38 \%$ & $12.79 \%$ & $20.00 \%$ \\
\hline 17 & $8.76 \%$ & $5.63 \%$ & $8.53 \%$ & $8.78 \%$ & $7.39 \%$ & $0.07 \%$ & $5.34 \%$ & $8.57 \%$ & $17.87 \%$ \\
\hline 18 & $3.89 \%$ & $0.91 \%$ & $4.51 \%$ & $4.16 \%$ & $4.59 \%$ & $0.05 \%$ & $2.30 \%$ & $4.36 \%$ & $11.30 \%$ \\
\hline 19 & $0.00 \%$ & $0.00 \%$ & $0.24 \%$ & $0.00 \%$ & $1.36 \%$ & $0.03 \%$ & $0.00 \%$ & $0.14 \%$ & $4.70 \%$ \\
\hline 20 & $0.00 \%$ & $0.00 \%$ & $0.00 \%$ & $0.00 \%$ & $0.00 \%$ & $0.00 \%$ & $0.00 \%$ & $0.00 \%$ & $0.00 \%$ \\
\hline \multicolumn{10}{|c|}{ Panel B: Level of Risk Reduction } \\
\hline 1 & -0.0539 & -0.0275 & -0.0801 & -0.0883 & 1169 & -0.0846 & -0.1141 & -0.1596 & -0.3069 \\
\hline 2 & -0.0335 & -0.0230 & -0.0751 & -0.0702 & -0.0708 & -0.0427 & -0.0591 & -0.0888 & -0.2556 \\
\hline 3 & -0.0316 & -0.0224 & -0.0755 & -0.0695 & -0.0416 & -0.0196 & -0.0487 & -0.0623 & -0.2061 \\
\hline 4 & -0.0307 & -0.0231 & -0.0767 & -0.0695 & -0.0345 & -0.0148 & -0.0477 & -0.0650 & -0.1685 \\
\hline 5 & -0.0306 & -0.0242 & -0.0788 & -0.0703 & -0.0293 & -0.0112 & -0.0484 & -0.0673 & -0.1467 \\
\hline 6 & -0.0312 & -0.0253 & -0.0817 & -0.0716 & -0.0246 & -0.0082 & -0.0502 & -0.0695 & -0.1506 \\
\hline 7 & -0.0323 & -0.0264 & -0.0870 & -0.0737 & -0.0191 & -0.0057 & -0.0522 & -0.0713 & -0.1535 \\
\hline 8 & -0.0336 & -0.0274 & -0.0940 & -0.0793 & -0.0142 & -0.0020 & -0.0540 & -0.0730 & -0.1560 \\
\hline 9 & -0.0349 & -0.0285 & -0.0990 & -0.0856 & -0.0119 & 0.0000 & -0.0559 & -0.0746 & -0.1584 \\
\hline 10 & -0.0364 & -0.0297 & -0.1017 & -0.0881 & -0.0123 & 0.0000 & -0.0578 & -0.0761 & -0.1606 \\
\hline 11 & -0.0381 & -0.0312 & -0.1043 & -0.0906 & -0.0127 & 0.0000 & -0.0595 & -0.0775 & -0.1626 \\
\hline 12 & -0.0401 & -0.0329 & -0.1069 & -0.0929 & -0.0130 & 0.0000 & -0.0612 & -0.0788 & -0.1645 \\
\hline 13 & -0.0421 & -0.0346 & -0.1092 & -0.0950 & -0.0132 & 0.0000 & -0.0624 & -0.0801 & -0.1666 \\
\hline 14 & -0.0440 & -0.0351 & -0.1114 & -0.0970 & -0.0132 & 0.0000 & -0.0594 & -0.0812 & -0.1684 \\
\hline 15 & -0.0448 & -0.0309 & -0.1020 & -0.0919 & -0.0134 & 0.0000 & -0.0516 & -0.0731 & -0.1702 \\
\hline 16 & -0.0392 & -0.0232 & -0.0782 & -0.0723 & -0.0135 & 0.0000 & -0.0393 & -0.0584 & -0.1717 \\
\hline 17 & -0.0280 & -0.0137 & -0.0451 & -0.0456 & -0.0124 & 0.0000 & -0.0232 & -0.0390 & -0.1545 \\
\hline 18 & -0.0114 & -0.0018 & -0.0080 & -0.0149 & -0.0087 & 0.0000 & -0.0052 & -0.0154 & -0.1054 \\
\hline 19 & 0.0000 & 0.0000 & 0.0000 & 0.0000 & -0.0025 & 0.0000 & 0.0000 & 0.0000 & -0.0447 \\
\hline 20 & 00.000 & 0.0000 & 0.0000 & 0.0000 & 0.0000 & 0.0000 & 0.0000 & 0.0000 & 0.0000 \\
\hline
\end{tabular}


Exhibit 8A: Allocations and Level of Risk Reduction for Twenty Year Time Horizons

\begin{tabular}{|c|c|c|c|c|}
\hline & 1999 & 2000 & 2001 & 2002 \\
\hline \multicolumn{5}{|c|}{ Panel A: REIT Allocations } \\
\hline 1 & $8.72 \%$ & $14.75 \%$ & $17.96 \%$ & $19.69 \%$ \\
\hline 2 & $8.75 \%$ & $16.11 \%$ & $19.45 \%$ & $20.00 \%$ \\
\hline 3 & $9.06 \%$ & $17.48 \%$ & $20.00 \%$ & $20.00 \%$ \\
\hline 4 & $9.36 \%$ & $18.84 \%$ & $20.00 \%$ & $20.00 \%$ \\
\hline 5 & $9.67 \%$ & $20.00 \%$ & $20.00 \%$ & $20.00 \%$ \\
\hline 6 & $9.98 \%$ & $20.00 \%$ & $20.00 \%$ & $20.00 \%$ \\
\hline 7 & $10.29 \%$ & $20.00 \%$ & $20.00 \%$ & $20.00 \%$ \\
\hline 8 & $10.59 \%$ & $20.00 \%$ & $20.00 \%$ & $20.00 \%$ \\
\hline 9 & $10.90 \%$ & $20.00 \%$ & $20.00 \%$ & $20.00 \%$ \\
\hline 10 & $11.21 \%$ & $20.00 \%$ & $20.00 \%$ & $20.00 \%$ \\
\hline 11 & $11.52 \%$ & $20.00 \%$ & $20.00 \%$ & $20.00 \%$ \\
\hline 12 & $11.82 \%$ & $20.00 \%$ & $20.00 \%$ & $20.00 \%$ \\
\hline 13 & $12.13 \%$ & $20.00 \%$ & $20.00 \%$ & $20.00 \%$ \\
\hline 14 & $12.44 \%$ & $15.83 \%$ & $20.00 \%$ & $20.00 \%$ \\
\hline 15 & $11.58 \%$ & $12.27 \%$ & $18.55 \%$ & $20.00 \%$ \\
\hline 16 & $7.43 \%$ & $7.83 \%$ & $14.15 \%$ & $18.91 \%$ \\
\hline 17 & $3.36 \%$ & $2.63 \%$ & $8.57 \%$ & $13.04 \%$ \\
\hline 18 & $0.00 \%$ & $0.00 \%$ & $3.00 \%$ & $7.18 \%$ \\
\hline 19 & $0.00 \%$ & $0.00 \%$ & $0.00 \%$ & $1.31 \%$ \\
\hline 20 & $0.00 \%$ & $0.00 \%$ & $0.00 \%$ & $0.00 \%$ \\
\hline \multicolumn{5}{|c|}{ Panel B: Level of Risk Reduction } \\
\hline 1 & -0.0506 & -0.0711 & -0.1221 & -0.1801 \\
\hline 2 & -0.0233 & -0.0619 & -0.1015 & -0.1505 \\
\hline 3 & -0.0202 & -0.0644 & -0.1075 & -0.1412 \\
\hline 4 & -0.0188 & -0.0678 & -0.1119 & -0.1445 \\
\hline 5 & -0.0189 & -0.0712 & -0.1145 & -0.1502 \\
\hline 6 & -0.0195 & -0.0741 & -0.1158 & -0.1552 \\
\hline 7 & -0.0202 & -0.0769 & -0.1169 & -0.1588 \\
\hline 8 & -0.0208 & -0.0794 & -0.1180 & -0.1612 \\
\hline 9 & -0.0215 & -0.0818 & -0.1196 & -0.1632 \\
\hline 10 & -0.0222 & -0.0840 & -0.1216 & -0.1646 \\
\hline 11 & -0.0229 & -0.0861 & -0.1239 & -0.1660 \\
\hline 12 & -0.0235 & -0.0881 & -0.1260 & -0.1673 \\
\hline 13 & -0.0242 & -0.0897 & -0.1279 & -0.1691 \\
\hline 14 & -0.0250 & -0.0778 & -0.1250 & -0.1709 \\
\hline 15 & -0.0257 & -0.0579 & -0.1036 & -0.1721 \\
\hline 16 & -0.0219 & -0.0333 & -0.0752 & -0.1522 \\
\hline 17 & -0.0121 & -0.0064 & -0.0399 & -0.1103 \\
\hline 18 & 0.0000 & 0.0000 & -0.0086 & -0.0601 \\
\hline 19 & 0.0000 & 0.0000 & 0.0000 & -0.0080 \\
\hline 20 & 0.0000 & 0.0000 & 0.0000 & 0.0000 \\
\hline
\end{tabular}

